This is the final peer-reviewed accepted manuscript of:

Bottazzi, L., Da Rin, M., \& Hellmann, T. (2016). The importance of trust for investment: Evidence from venture capital. The Review of Financial Studies, 29(9), 2283-2318

The final published version is available online at:

https://doi.org/10.1093/rfs/hhw023

Rights / License:

The terms and conditions for the reuse of this version of the manuscript are specified in the publishing policy. For all terms of use and more information see the publisher's website.

This item was downloaded from IRIS Università di Bologna (https://cris.unibo.it/)

When citing, please refer to the published version. 


\title{
The Importance of Trust for Investment: Evidence from Venture Capital
}

\author{
Laura Bottazzi* \\ Bologna University and IGIER \\ Marco Da Rin
Tilburg University \\ Thomas Hellmann \\ Saïd Business School, University of Oxford and NBER
}

March 2016

\begin{abstract}
We examine the effect of trust in venture capital. Our theory predicts a positive relationship of trust with investment, but a negative relationship with success. Using a hand-collected dataset of European venture capital deals, we find that the Eurobarometer measure of trust among nations positively predicts venture capital firms' investment decisions, but that it has a negative correlation with successful exits. Our theory also predicts that earlier stage investments require higher trust, that syndication is more valuable in low trust situations, and that higher trust investors use more contingent contracts. The empirical evidence supports these predictions.
\end{abstract}

\section{Forthcoming, Review of Financial Studies}

\footnotetext{
${ }^{*}$ Marco Da Rin is also affiliated with the European Corporate Governance Institute (ECGI). Laura Bottazzi is also affiliated with the Rimini Center of Economic Resarch (RCER). We thank Manuel Arellano, Jim Brander, Bruce Carlin, Francesco Corielli, Serdar Dinç, Alex Dyck, Florian Ederer, Dan Elfenbein, Daniel Ferreira, Patrick Francois, Keith Head, Ulrich Hege, Yael Hochberg, Tobias Klein, Chiara Monfardini, Ramana Nanda, Frank Packer, Michele Pellizzari, Enrico Perotti, Mitch Petersen, Paola Sapienza, Per Strömberg, Ravi Singh, Morten Sørensen, Scott Stern, Alexander Wagner, Ralph Winter, Rebecca Zarutskie, Luigi Zingales, and participants to several conferences and and to seminars at Bocconi University, CEMFI, Industry Canada (Ottawa), Indian School of Business, MIT (Sloan), Northwestern University (Kellogg), Rennsselaer Polytech (Lally), University of British Columbia (Sauder School), University of Toronto (Rotman), University of Washington, St. Louis (Olin), and University of Wisconsin (Madison). We are grateful to all the venture capital firms that provided us with data. We thank Roberto Bonfatti, Michela Braga, Matteo Ercole, Alessandro Gavazzeni, and Eric Hensen for research assistance. Financial support from the W. Maurice Young Entrepreneurship and Venture Capital Research Centre, the Italian Ministry of Research (FIRB grant RBAU013CNJ) and the European Commission (grant CIT5-CT-2006028942) is gratefully acknowledged. All errors remain our own.
} 
"There are countries in Europe [...] where the most serious impediment to conducting business concerns on a large scale, is the rarity of persons who are supposed fit to be trusted with the receipt and expenditure of large sums of money." (John Stuart Mill)

Many economists have intuitively recognized the importance of trust for economic transactions. Since Arrow's (1973) remark that "virtually every commercial transaction has within itself an element of trust" a growing literature has analyzed the role of trust in economic decisions. For example, the work of Knack and Keefer (1997), Temple and Johnson (1998), and Zak and Knack (2001) establishes a positive relationship between trust and economic growth. More recently, Guiso, Sapienza and Zingales (2009) study the importance of trust for bilateral trade in goods, financial assets, and direct foreign investment, and Guiso, Sapienza and Zingales (2008) use Dutch and Italian data to establish an effect of trust on stock market participation.

In this paper we ask whether trust among nations affects the decision to make an investment across different countries, how trust is related to investment success, and how trust affects deal structures. Following the social capital literature, we define trust as a subjective belief about the likelihood that a potential trading partner will act honestly. It is important to distinguish two different types of trust. Generalized trust pertains to the preconceptions that people of one identifiable group have for people from another identifiable group. Personalized trust, instead, concerns the evolving relationship between two specific agents. In this paper we focus solely on generalized trust, so that we are concerned with what might be considered cursory beliefs, generalizations about others, even stereotypes. Moreover, generalized trust does not necessarily pertain to the specific company than an investor deals with, but in may pertain to the company's countrymen and country institutions that can influence the investment outcome.

A natural null hypothesis is that trust does not matter at all. Conceptually one might think that venture capitalists are sophisticated professional investors who should not be swayed by popular trust stereotypes. They might also be able to arbitrage any irrational trust differentials. As an alternative, we develop a simple model that shows how trust can matter in a rational equilibrium model. In our theory a focal investor considers investing in a company. Trust affects the likelihood that investors will actually get their returns in case of success.

The model makes three central predictions. First, the probability that investors makes an investment is positively related to their level of trust, where trust is always relative. Second, there is a negative relationship between trust and the success rate of investments. This is because of a selection effect, where higher trust investors are relatively more willing to invest in higher risk companies. Third, the model makes several predictions on how trust should be related to investment stage, syndication, and contingent contracts, as discussed below.

To test the model predictions we use a hand-collected dataset of European venture capital investments made between 1998 and 2001 that contains investors and companies from 15 European Union countries, Norway, Switzerland, and the US. One of the advantages of using microeconomic data is that reverse causality can be safely dismissed: trust among nations can affect venture capital investments, but the venture capital industry is clearly too small to influence the trust among nations. Given the inherently subjective nature of 
trust, it is appropriate to measure it by surveying opinions. We adopt the approach of Guiso, Sapienza and Zingales (2009) of using the Eurobarometer survey data of bilateral trust among nations. This measure is based on how much citizens of one country say they trust the citizens of each other country (including their own).

The data clearly rejects the null hypothesis of no trust effects. There is a positive effect of trust on investments. The effect is highly significant, both statistically and economically. A one percentage point increase in those who have high trust towards another country implies an almost seven percentage point increase in the probability that an investment is made.

Our econometric specification considers all potential financing deals between investors and companies in our sample and asks which deals are actually realized. We use a set of fixed effects, most notably company and investor fixed effects. The Eurobarometer measure of generalized trust varies at the country-dyadic level. Given our fixed effects, it only measures the relative (or dyadic) trust distance between investor and company. To isolate the effect of trust and eliminate alternative explanations we control for a large set of other country-dyadic variables, such as differences in GDP, legal origin, language overlap, common borders, and even the amount of information about foreign countries available in the business press. We also control for several variables that vary at the companyinvestor-dyadic level, such as their physical distance, or the investor's propensity to invest in the company's stage and industry. We provide numerous robustness checks, including alternative ways of measuring trust.

Obtaining data on venture capital returns is fraught with difficulty, so we use the standard approach in the literature of focusing on investment outcomes - see Da Rin, Hellmann and Puri (2013) for a discussion. We consider three measures: (i) IPOs, which are relatively few but clearly associated with high returns; (ii) EXIT, a measure which also includes acquisitions - a more frequent but also a noisier measure of success; and (iii) FAILURE, which identifies companies that have gone out of business. Our evidence points to a negative relationship between trust and successful outcomes. We consider a variety of models and find that the coefficients for trust are always negative for the IPO and EXIT, and always positive for the FAILURE. They are often, but not always, statistically significant.

Our theory suggests that the negative relationship between trust and success is driven by selection effects. We look for evidence of such effects by considering both selection on observable and unobservable characteristics. To test for selection on observables we construct an index that maps the company information available at the time of investment into predicted outcome probabilities. We find a highly significant negative correlation between trust and these predicted outcome indices. To test for selection on unobservables we estimate a Heckman selection using a plausible exclusion restriction. Our focus is on the Mills ratio which estimates correlation amongst the unobservables. We find mild evidence for such unobservable selection effects.

Our final research question concerns the relationship of trust to deal structures. Our theory generates three main predictions, namely that early stage deals require higher trust, that syndication becomes more attractive in low trust deals, and that contingent contracts are more likely to be used in high trust deals. We leverage our hand-collected data to empirically evaluate these predictions, and find empirical evidence that is supportive of all three predictions. 
Our paper builds on, and contributes to, a number of literatures. Most closely related is the literature about the effects of trust on financial decisions. Guiso, Sapienza and Zingales (2008) document that trust affects the willingness to invest money in shares, and thus contribute to explaining limited participation in the stock market. We examine the decision to invest not by individuals who allocate their savings to liquid markets, but by sophisticated financial intermediaries that invest in illiquid companies. Moreover, Guiso, Sapienza and Zingales (2009) establish the importance of trust for aggregate trade and foreign direct investment flows. We provide an analysis that is complementary yet distinct. Their analysis remains at the macro level, i.e., at the level of country pairs. We are able to analyze data at the level of individual investor-company pairs. Our deal-level data permits us to control for a comprehensive set of alternative explanatory factors, and thus to better isolate the role of trust. Because we focus on a small segment of the economy, we can also safely eliminate any concerns about reverse causality. We can thus bypass the difficulties of having to find appropriate instruments for the determinants of trust. Importantly, we also address the question of how trust is related to investment success and deal structure.

Our paper makes a novel contribution to the venture capital literature by addressing deal formation, an issue that has received surprisingly little attention so far. Two recent exceptions are Bengtsson and Hsu (2010) and Hegde and Tumlinson (2014) who use similar empirical approaches to ours and find evidence of assortative matching for investors and entrepreneurs from same ethnic background. Our paper introduces trust as an important factor for deal formation. ${ }^{1}$

Our paper also contributes to research on the 'home bias' investment puzzle. ${ }^{2}$ Our analysis goes beyond previous work by examining not only whether transactions occur, but also how they perform. We also contribute to the recent literature on cross-border venture investments, looking at what factors influence the choice of investing abroad and at syndication and staging in foreign deals - see Balcarcel, Hertzel, and Lindsey (2010), and Chemmanur, Hull, and Krishan (2011). Note also that because of investor country fixed effects our analysis already absorbs all cross-country differences in legal systems, so that the effects of trust we document go beyond differences in legal systems. ${ }^{3}$

Finally, our study contributes to the broader literature on the economic effects of social capital (see Durlauf and Fafchamps (2006) and Guiso, Sapienza and Zingales (2006) for useful surveys). Ekinci, Kalemli-Ozcan, and Sorensen (2007) investigate the effect of social capital on financial integration among European regions, finding that regions where the level of confidence and trust is high are more financially integrated with each other. ${ }^{4}$

The remainder of the paper is structured as follows. Section 1 describes the theory. Section 2 explains our data and variables. Section 3 examines the effect of trust on deal

\footnotetext{
${ }^{1}$ The work of Ahern, Daminelli, and Fracassi (2015) is also related. They find that the amount of trusting within different nations is negatively related to both the volume of mergers and the combined merger announcement returns.

${ }^{2}$ See Bae, Stulz and Tan (2008), Bottazzi, Pesenti, and van Wincoop (1996), French and Poterba (1991), and the survey by Karolyi and Stulz (2003).

${ }^{3}$ See also Bottazzi, Da Rin and Hellmann (2009), Cumming, Schmidt and Walz (2010), Kaplan, Martel and Strömberg (2007), and Lerner and Schoar (2005).

${ }^{4}$ Also related to our paper is the work of Bloom, Sadun, and van Reenen (2012), which analyzes managerial practices at multinational companies around the world. They show that firms located in areas with higher trust tend to be in industries that rely on decentralization. Moreover, they find that trust facilitates delegation from the headquarters by improving cooperation.
} 
formation. Section 4 examines the relationship between trust and investment success. Section 5 tests the predictions about deal structure. It is followed by a brief conclusion. The online Appendix contains all theory proofs and a more extensive discussion of the empirical robustness checks.

\section{Theory}

\subsection{Generalized trust}

In this paper we use a commonly accepted definition of trust, as "the subjective probability with which an agent assesses that another agent or group of agents will perform a particular action." ${ }^{5}$ Two different types of trust are relevant for our study: personalized trust and generalized trust. Personalized trust is a set of beliefs that one person has about the behavior of another specific person. It is based on a repeated interaction between the two individuals and can thus be thought of as an informed belief. Generalized trust, by contrast, is a set of beliefs about the behavior of a random member of an identifiable group of individuals. Durlauf and Fafchamps (2006) argue that "the main difference between the two is that, for each pair of newly matched agents, the former takes time and effort to establish, while the latter is instantaneous." From an economics perspective, the difference between generalized and personalized trust can be thought of as the difference between general prior beliefs versus specific posterior beliefs. Moreover, personalized trust focuses on a specific trading partner, whereas generalized trust also concerns the behavior of third parties that are not directly part of the transaction, or more broadly the 'institutions' that govern transactions in the partner's country. Furthermore, from an econometric perspective, a key difference is that generalized trust is exogenous to the specific microeconomic transaction, whereas personalized trust is inherently endogenous.

This distinction is particularly relevant in the venture context. A venture capital investor ('VC' henceforth) and an entrepreneur typically do not know each other before contracting. After investing, they work closely together (Hellmann and Puri (2002)). At the beginning of their relationship, the (generalized) trust between a potential VC and an entrepreneur is exogenous. Once their relationship has developed, trust becomes personalized and endogenous to the numerous decisions and interactions made along the way. In our study we focus solely on generalized trust. Importantly, we note that this trust concerns not only what investors believe about a specific entrepreneur, but also what they believe about the entrepreneur's countrymen and institutions.

In any actual investment decision we might expect generalized and personalized trust to be co-mingled, both affecting whether and how the transaction takes place. In our empirical analysis we have a measure for generalized trust, but not for personalized trust. If the two types of trust were independent of each other, then the absence of a personalized trust measure would not affect any estimated effects of generalized trust. However, one might think that the two types of trust are correlated; indeed one can think of generalized trust as the systematic component of all personalized trust relationships. In this case the estimated coefficient of generalized trust would pick up the correlated component

\footnotetext{
${ }^{5}$ A large literature which spans several social sciences examines the concept of trust and its effects on human behavior. Guiso, Sapienza and Zingales (2006), Möllering (2006), and Nooteboom (2002) review this literature from different angles.
} 
of an unobserved personalized trust effect. We should therefore interpret our estimated generalized trust coefficients as total effects, not as partial effects that are net of personalized trust. Importantly, we believe that generalized trust is exogenous but personalized trust endogenous. The correlated component is presumably the part of personalized trust that can be traced back to generalized trust. Consequently we would argue that it is appropriate for us to focus on the total effect of generalized trust. At the same time we acknowledge that personalized trust likely matters for investments too. While we do not have the data to do so, future research might try to further disentangle these two types of trust.

\subsection{A theory of trust in venture capital}

Our model aims to address three fundamental questions. First, how are VC investments decisions affected by generalized trust? Second, what is the relationship between trust and investment success? Third, how is trust related to deal structures? To address these questions, we develop a simple model, which bears some similarities to the trust model of Ahern, Daminelli, and Fracassi (2015) and is developed in the online Appendix.

In the model there is a focal investor that competes against a competitive fringe to invest in a risky company. The focal investor has differentiated skills, and may have different trust relative to the fringe investors. In the model there is a problem of ex-post rent dissipation, where third parties may capture some of the rents. Trust affects the fraction of returns that investors can retain in their successful investment outcomes. The main propositions that arise from our theory are as follows.

Proposition 1: The probability of making an investment is increasing in relative trust.

The intuition is that higher relative trust extends the range where investors finds it worthwhile to outbid their competitors.

Proposition 2: The average success rate is decreasing in relative trust.

The intuition is that while higher trust allows investors to extend the range of companies they finance, those additional companies are marginal companies with lower success probabilities. Their addition into the portfolio therefore reduces the investors' average success rate.

A prior literature explores how VC fund companis across multiple investment stages (see Da Rin, Hellmann, and Puri (2013) for an overview). Rent dissipation is likely to be a bigger problem in earlier stage deals, because of the lack of tangible assets.

Proposition 3: The higher the investors' trust, the more they are willing to invest in earlier stages.

The intuition is that earlier stages expose investors to greater dangers of rent dissipation. Consequently only those investors that have sufficiently high trust are willing to risk investing in those earlier stages.

A fundamental question in every deal is exactly who is investing. Of particular importance is the decision whether to invite syndication partners into a deal. We build on the seminal work of Brander, Amit, and Antweiler (2002) by examining a trade-off between the cost of sharing a deal versus the benefit of obtaining synergies. 
Proposition 4: The likelihood of syndication is a decreasing function of trust.

The intuition is that at higher levels of trust, the cost of sharing deals increases, because deals become more valuable. This makes investors less willing to share their deals with syndicate partners.

The seminal work of Kaplan and Strömberg (2003, 2004) highlights the role of VC contracts. They emphasize the importance of contingent contracting clauses that shift cash flows rights as a function of contractible milestone events. Our stylized model builds on Hellmann (2006) who views contingent contracts as an efficient transfer of cash flow rights from one party to another in some, but not other, verifiable states.

Proposition 5: The use of contingent contracts is increasing with trust.

The intuition is that the lack of trust interferes with the efficient reallocation of cash flow rights. In the absence of any trust problems, contingent contracts would be efficient whenever contingent transfers increase expected returns. However, lack of trust reduces the value of contingent transfers because of the rent dissipation.

\subsection{Further theory discussion}

It is useful to contrast our propositions to the null hypothesis that trust has no effect. One version of the null hypothesis is that rationally there should be no systematic differences in generalized trust. If agents have common priors and update them based on all the available information, no systematic trust differences should persist. One obvious problem with this critique is that it doesn't seem to be supported by the data; in section 3.4 we show that trust differentials are pervasive and remarkably persistent. Even from a purely theoretical perspective, the assumption of common priors need not always hold. Morris (1995) discusses how non-common priors can persist when there is limited information exchange and limited updating of beliefs, conditions that are likely to hold in VC. In addition, there may also be equilibrium reasons why third-party rent capture is easier with some investors than others. The work of Greif (1993), for example, notes that there can be multiple equilibria with different self-fulfilling levels of trust amongst agents. This clarifies that trust differentials are not inconsistent with rational behavior.

Another version of the null hypothesis is that even if trust differences persist, they should not matter, because sophisticated investors can undo them by taking advantage of arbitrage opportunities. This argument seems applicable to liquid and transparent markets, but is less convincing in VC, where arbitrage requires a long horizon. Moreover, we note again that lack of trust can be self-fulfilling (Greif (1993)). Arbitrage may not work to get out of a low equilibrium because the counter-party also has low trust.

In our model trust affects investment through the investors' participation constraint. Another potential channel for trust to matter could be at the preceding search stage, where entrepreneurs and VCs find each other. For example, a VC firm with low generalized trust of an entrepreneur's country may never take much interest in business plans from that country. Similarly, an entrepreneur who has low generalized trust of a VC firm may never bother to initiate contact. Thus a model that focuses on the earlier search part of the investment process would generate very similar predictions to ours. ${ }^{6}$

\footnotetext{
${ }^{6}$ Closely related to this, social networks may be the channel through which trust operates. Sociologists
} 
One can also think of alternative theories concerning the relationship between trust and success. Our theory is driven by a selection effect, where higher trust investors make more investments in lower quality companies. An alternative is to think about how trust affects VC 'treatment effects'. A natural conjecture is that higher trust encourages investors to provide more value-added support. A large prior literature models the value-added role of VC in terms of private efforts (see Da Rin, Hellmann, and Puri (2013)). In the online Appendix we briefly outline how to augment our base model to account for this. We show that for a given company, higher trust encourages investors to provide more value-adding effort. However, higher trust investors invest in more marginal companies that receive relatively less effort. The overall effect of trust on value-adding effort therefore remains ambiguous. We return to this in our empirical discussion of selection versus treatment effects in section 5.2.

\section{Data and variables}

In this section we describe our data sources and motivate our variables, which are defined in Table 1. The online Appendix Descriptive Statistics Table provides descriptive statistics for all dependent and independent variables, and the Appendix Correlations Table reports pairwise correlations among variables.

\subsection{Data sources}

Our data comes from a variety of sources. The main data are gathered through a survey of $685 \mathrm{VC}$ firms in 15 European Union countries: Austria, Belgium, Denmark, Finland, France, Germany, Greece, Ireland, Italy, Luxembourg, the Netherlands, Portugal, Spain, Sweden, and the UK. Venture firms were included in our sample if they : (i) were full members of the European Venture Capital Association (EVCA) or of a national VC organization in 2001, (ii) were actively engaged in VC and (iii) were still in operations in 2002. The survey asked detailed information on all first rounds of VC investments made between January 1998 and December 2001, as well as information on the venture firm's partners. ${ }^{7}$ We exclude buyout investments.

We received 107 usable responses, which we cross-checked using investor and company websites, commercial databases, and trade publications. The resulting dataset represents a comprehensive cross-section which provides a good coverage of all countries, with an overall response rate of nearly $16 \%$, a rate significantly larger than for comparable surveys of industrial firms (see Graham and Harvey (2001)). No single country dominates the sample, and no country is left out. Our data are not dominated by a few respondents: the largest $\mathrm{VC}$ firm accounts for only $5 \%$ of the observations, and the largest five for only

have long argued that the likelihood that two partners engage in an economic transaction depends on their social networks (see, for example, Granovetter (1995)). In the context of venture capital, it seems plausible that social networks facilitate the process of search (see Sorenson and Stuart (2001) and Hochberg, Ljungqvist, and Liu (2007)). Naturally, social networks themselves are endogenous, and likely to form along the fault lines of generalized trust. Social networks should thus not necessarily be viewed as the underlying drivers. We therefore consider social networks not as an alternative hypothesis, but one of the endogenous channels through which trust can affect the formation and structure of venture capital investments.

${ }^{7}$ We use the term 'firm' for the investor (i.e., the venture capital firm) and the term 'company' for the company that receives the venture capital financing. 
16\%. Bottazzi, Da Rin and Hellmann $(2008,2009)$ provide a more extensive discussion of the data, and report additional tests that confirm the representativeness of the sample.

One may wonder about the relative advantages of using our hand-collected data, relative to commercial databases such as ThomsonOne. One important advantage of our data is that we are able to collect additional information not available in ThomsonOne, most notably data on the contractual arrangements between entrepreneurs and investors. ${ }^{8}$

The main independent variable is the trust from citizens of one country towards citizens of another country. This variable is collected by Eurostat through the yearly Eurobarometer survey of citizens of all European countries. We report in Table 1 the sources for all other independent variables.

\subsection{Unit of observation}

We adopt two units of observation. In the first part of the analysis, we focus on the decision to invest, i.e., whether to make a deal or not. For this we construct the sample of all potential deals, consisting of every possible pairing between the 107 investors and their 1,170 portfolio companies. Portfolio companies are located in one of the 15 European Union countries venture investors are from; they are also located in Norway, Switzerland, and the US, since Eurostat collects data on trust in citizens of those countries. The unit of observation is the individual investor-company pair (as in Sørensen (2007)). For each company we consider that it could in principle be financed by any of the respondent venture firms; we take into account that some pairs are not feasible because the VC began operations after the date the company was seeking an investment. Our potential deals dataset includes 101,620 potential deals.

We analyze investment decisions in a discrete choice framework where investors choose among companies as investment alternatives. In addition to a logit model, we use a conditional logit model where, in the terminology of McFadden (1984), we think of investors as cases and companies as the alternatives. This approach takes the investors' perspective which corresponds to our survey design. In this set-up the trust variable measures how people from the investor's country trust people from the company's country. While investors choose companies, those companies also choose to accept the investments. We therefore also estimate our model treating companies as cases and investors as alternatives, in which case the trust variable measures how people from the company's country trust people from the investor's country.

One feature of our analysis is that to be included in our sample, a company must have received funding from at least one investor. We clearly cannot observe all the 'marginal' companies that never received any funding from any VC. ${ }^{9}$ Our analysis therefore examines

\footnotetext{
${ }^{8}$ In addition we compared our data to the data from ThomsonOne for the 52 VCs that are present in both our survey data and the ThomsonOne data. Specifically, we gathered all the data from ThomsonOne for the same sample period and same countries. We find $500 \mathrm{VC}$ investors and 1,965 companies. We also manually augment the data to obtain investment outcomes (IPOs, acquisitions and failures) for all 1,965 companies, up to the same cut-off date, to ensure consistency with our data. In our sample these VCs report on average 15.4 deals, yet ThomsonOne only reports an average of only 4.8 deals. This suggests that ThomsonOne captures a smaller fraction of the investments made by these European VCs. We therefore use our data as our primary source. Still we report in the Appendix robustness checks based on the ThomsonOne data.

${ }^{9}$ Note that even if we did, their observations would fall out of the regression by the time we consider
} 
whether trust affects investment decisions among all 'infra-marginal' companies, excluding any effect that trust may have on the marginal companies. It is possible that higher levels of trust increase the size of the VC market. Indeed, Figure 1 shows a positive correlation of 0.51 (significant at the $6 \%$ confidence level) between the size of the VC market, measured by aggregate investment (relative to per-capita GDP), and the level of trust received by each country. This is also consistent with the predictions of our theory.

In the second part of the analysis we focus on the relationship between trust and investment success, and in the third part on the relationship between trust and deal structure. For these parts of the analysis we use what we call the realized deals sample, which consists of all the investments that we observe in our data. Our realized deals sample contains a total of 1,228 deals, into 1,170 companies, made by $107 \mathrm{VC}$ firms. ${ }^{10}$

\subsection{Dependent variables}

In the first part of the analysis we ask whether a particular investor finances a particular company. The dependent variable is DEAL, which is a dummy variable that takes the value 1 if the $\mathrm{VC}$ firm has invested in a particular company and 0 otherwise.

In the second part of the analysis we examine what type of outcomes companies have experienced and how financing deals are structured. We assess investment success as of August 2011, almost ten years after the end of our sample frame using commercial databases (Amadeus, ThomsonOne, and Worldscope), press articles (using Lexis-Nexis), and web searches. Given the highly skewed nature of investment performance in venture capital, we follow previous studies (see for instance Phalippou and Gottschalk (2009)) and measure performance in terms of outcomes. For this, we classify companies into five distinct exit outcome categories: (i) the company had an IPO; (ii) the company was acquired; (iii) the company went out of business; (iv) the company is still in the venture firm's portfolio and operating; and ( $v$ ) the company cannot be traced. We aggregate these categories into three variables that have a clear economic interpretation. IPOs provide the most successful outcome for investors. Therefore, IPO measures whether a company went public or not. The second dependent variable, EXIT, includes both IPOs and acquisitions. EXIT is a broader, but likely noisier, measure of investment success. The third dependent variable, FAILURE, identifies companies that went out of business or whose situation cannot be traced. These 'untraceable' companies can be reasonably considered a failure because venture firms typically report the exit of portfolio companies to the business press and on their websites.

We build additional dependent variables for deal structure, which we describe in Sections 5.1, and 5, 2, and for contracting, which we describe in Section 5.3.

\subsection{Independent variables}

Our analysis is based on the Eurobarometer measures of trust, that was previously used, and described in detail, by Guiso, Sapienza and Zingales (2009). Eurobarometer is a large survey about the social and political attitudes of citizens of the European Union that is

\footnotetext{
the conditional logit model.

${ }^{10}$ There are more deals than companies because 51 companies receive financing from more than one of our venture investors. In the Appendix we also discuss why the actual number of observations used in the regression changes across different specifications.
} 
executed yearly for the European Commission since 1970. Our trust measure is derived from the Eurobarometer survey waves from 1990 to $1996 .^{11}$. Specifically, we define trust as the percentage of the citizens in one country that trust a lot people from the other country, as in Bloom, Sadun, and van Reenen (2012).

How reliable is this measure of trust? First, the trust measure reflects patterns one would intuitively expect: people typically have the highest trust for their own country; Scandinavian countries receive high trust, and are also more trusting; the British trust the French less than other nations; and the French are happy to reciprocate. Second, the Eurobarometer trust measure has a strong correlation with the World Values Survey (WVS) measure of trusting, which has been used by several studies (e.g., Knack and Keefer (1997)). The correlation coefficient is 0.72 , significant at the $1 \%$ level. $^{12}$ This strong correlation suggests a reliable measurement of trust that does not depend on the details of how the surveys were implemented. We also notice that trust among nations is remarkably persistent over time: The correlation coefficients across Eurobarometer waves is often over $90 \%$ and always above $84 \%$.

The remaining country-dyadic variables are meant to capture other factors that should affect the investment decision, or that constitute potentially alternative explanations. We employ three variables that are standard controls in the literature on geography and trade: (i) whether an investor/company pair is either located in the same country or not, (ii) whether an investor/company pair is in neighboring countries (sharing a common border), and (iii) how economically far away are two countries, using the difference of the logarithmtransformed per-capita GDP. We then consider the role of search costs by looking at the amount of information on each country that is reported in another country's main business newspaper. We also consider two country-dyadic variables that capture transaction costs: the similarity of languages and of legal systems. To account for the intensity of economic relationships between countries we use one standard measure from the trade literature: the share of exports from country $i$ into country $j$ (in billions of dollars), averaged over the period from 1998 to 2001.

Our other independent variables vary at different levels. Three variables are measured at the level of the investor-company pair. First, we compute the log-transformed kilometer distance between the investor's and company's cities using the geodetic formula. ${ }^{13}$ Second, we compute two measures to capture an investor's propensity to make a deal in a company's industry and stage of financing: the share of investments of a VC firm in the same industry in which the company operates, and the share of investments of a $\mathrm{VC}$ firm in the same stage at which the company is receiving financing. We then consider several company characteristics: its country; its industry; the year in which the company received funding; and whether the company seeks early stage (seed or start-up) or late stage (expansion

\footnotetext{
${ }^{11}$ We do not collect trust data directly from our survey respondents, since such a measure would be endogenous to their investment experience. The Eurobarometer measure, on the contrary, is clearly exogenous to the investments made by venture capitalists.

${ }^{12}$ The WVS survey question is "Generally speaking, would you say that most people can be trusted, or that you can't be too careful in dealing with people?" The WVS therefore only measures how trusting citizens of one country are, rather than bilateral country-dyadic trust. Therefore, we compute the correlation coefficient using the Eurobarometer trust measure for citizens of the same country.

${ }^{13}$ Such precision allows us to avoid some of the measurement problems that have plagued the literature on trade and geography, which typically uses a much coarser measure - the distance between capital cities (see Head and Mayer (2010)).
} 
and bridge) financing. We also use a variety of fixed effects, sometimes controlling for investor fixed effects, sometimes controlling for company fixed effects, and sometimes for both. Whenever we don't control for company fixed effects, we use company country fixed effects. And whenever we don't control for investor fixed effects, we control for the following four investor characteristics: VC-SIZE, VC-AGE, INDEPENDENT-VC and US-EXPERIENCE. ${ }^{14}$ We discuss these approaches in more detail when we introduce our econometric approaches.

\section{Trust and deal formation}

In this section we empirically test Proposition 1, which predicts that higher relative trust leads to a higher probability of making an investment.

\subsection{Methodology}

We begin by asking what factors influence a VC's decision to invest in a company. Our unit of analysis is the sample of potential deals. We estimate the probability that a specific $\mathrm{VC}$ invests in a specific company with the following econometric model:

$$
D E A L_{p}=\alpha+X_{n}^{\prime} \beta^{n}+X_{p}^{\prime} \beta^{p}+X_{i}^{\prime} \beta^{i}+X_{c}^{\prime} \beta^{c}+\varepsilon_{p}
$$

Let $i$ index investors and $c$ index companies, let $p=(i, c)$ index investor-company (potential) pairs, and let $n$ index investor-company country dyads. The dependent variable is DEAL, which is a dummy variable for whether investor $i$ finances company $c$. The intercept term is denoted by $\alpha$. The vector $X_{n}^{\prime}$ represents variables that vary at the country-dyadic level, namely TRUST, FOREIGN-DEAL, COMMON-BORDER, INFORMATION, GDP-DIFFERENCE, LANGUAGE-OVERLAP, and LEGAL-DIFFERENCE. The vector $X_{p}^{\prime}$ represents variables that vary at the investor-company pair level, namely DISTANCE, INDUSTRY-FIT and STAGE-FIT. The vectors $X_{i}^{\prime}$ and $X_{c}^{\prime}$ represent variables that vary across investors and companies, respectively; we discuss them below.

To estimate the probability that a deal occurs, we use a logit model..$^{15}$ To control for investor characteristics we can afford to use a complete set of investor fixed effects, i.e., 107 dummies. This is clearly the most powerful way of controlling for any investor-specific effects, including the investor's nationality. The investor fixed effects also take care of any systematic differences across investors, including ability, preferences, and risk aversion. To control for company characteristics, we use INDUSTRY, STAGE and DEAL-DATE. In addition, we use company country fixed effects. This means that we control for the overall level of trustworthiness (e.g., on average the Swedes are trusted more than the Spaniards). It also accounts for any country-specific factors, such as regulation, taxes, institutions or country-specific investment opportunities. Importantly, our trust variables always reflect relative trust (e.g., relative to the average level of trust, the Spaniards are more trusted by the French than by the British). Moreover, the company country fixed

\footnotetext{
${ }^{14}$ The controls are founded in the prior VC literature. Kaplan and Schoar (2005) discuss the importance of VC size and age. Da Rin, Hellmann, and Puri (2013) discusses the large literature on independent versus captive VC. Kaplan, Martel and Strömberg (2007) emphasize the importance of US connections.

${ }^{15}$ Our results do not change when we use a probit.
} 
effects control for any country-specific effects, such as investment opportunities, the legal and institutional environment, and investor friendliness. The coefficient of trust therefore captures how deviations from the average level of trust towards the company's country affect the likelihood that an investor will make a deal with a company located in that country. With over one thousand companies in our sample we cannot add one fixed effect for every company. However, to control for all company characteristics, we can use a conditional logit model. This semi-parametric specification effectively includes both investor and company fixed effects, thus providing the richest possible set of controls. In all logit regressions we cluster the standard errors at the level of the country dyad, reflecting that our key independent variable TRUST varies at that level. However, such clustering violates the independence of individual errors across groups in the conditional logit, so that we use robust standard errors for those regressions.

We also want to distinguish trust from home bias. There are many reasons why investors may prefer to invest in a domestic company (Karolyi and Stulz (2003)). While trust may be one of those reasons - indeed people tend to express the highest trust for their own countrymen - we do not want to rely on a preference for domestic deals to identify the effect of trust. We therefore separately control for whether a company is located in the same or different country than the investor, as captured by the FOREIGN-DEAL dummy. Thus our estimate of the trust effect is conservative, as we eliminate one important channel through which trust may affect investments.

\subsection{Main results}

The estimates from the simple and conditional logit models are reported in Table 2. In column (i) we report the results of a logit estimation, and in column (ii) we report the results from the conditional logit model. We find that the coefficient on TRUST is positive and significant at the $1 \%$ level across all specifications. This clearly supports the hypothesis that trust affects the likelihood of making an investment. In addition to being statistically significant, the estimated coefficient measures an economically important effect. We focus on column (i) in Table 2, which is our main specification; results for the other specifications are very similar. The logit regression estimates the odds ratio, defined as the ratio of the probability of success to the probability of failure of the event (in our case of a deal being made). Consider a one point increase in the percentage of people that express high trust. An example (drawn near the median of the trust distribution) is that $15.3 \%$ of Spaniards have high trust for Germans, and $16.3 \%$ of Dutch have high trust for Germans. Such a one percentage point increase, averaged across the values of the covariates, generates a $5.7 \%$ increase in the probability of reaching a deal. Alternatively, consider moving from the 25th to the 75 th percentile of the trust distribution. For example, $10.5 \%$ of British people highly trust Germans, which is at the 25th percentile, while $24.8 \%$ of Norwegians highly trust Germans, which is at the 75 th percentile. Moving from the 25 th to the 75 th percentile of the trust distribution corresponds to a $119 \%$ increase in probability of reaching a deal-in other words, it more than doubles it. This magnitude is consistent with the results for portfolio investments of Guiso, Sapienza, and Zingales (2009).

Table 2 contains several other results. The coefficient of INFORMATION, which measures the percentage of newspaper coverage of the entrepreneurs' country, is positive and statistically highly significant. This suggests that search costs, broadly defined, matter. 
The result is somewhat surprising given the that our measure is only a rough proxy for differences in the amount of information available to investors. GDP-DIFFERENCE is negative and statistically significant. LANGUAGE-OVERLAP is positive, and LEGALDIFFERENCE is negative; neither is significant. Geographic distance is very important. The coefficient for DISTANCE has a negative sign and is statistically highly significant in all specifications. This confirms the notion that VC is a highly localized activity. The coefficient for FOREIGN-DEAL is negative and statistically significant in all four specifications. The coefficient for COMMON-BORDER is negative and significant when we include EXPORTS as regressors. Throughout all regressions we find that INDUSTRYFIT and STAGE-FIT have a highly significant effect, with a positive sign, as expected. This shows that specialization is an important aspect of the VC market: companies need to fit into investors' strategic preferences in order to attract investments.

The first two columns of Table 2, beyond using investor and company country fixed effects, already control for many alternative explanations other than trust. We can go even further and ask to what extent the relationship between trust and venture investments differs from the relationship between trust and trade, identified by Guiso, Sapienza and Zingales (2009). To examine this we include measures of trade as additional controls. One reason for doing this is that existing patterns of trade may facilitate venture investments. ${ }^{16}$ Columns (iii) and (iv) of Table 2 report the results of adding EXPORTS to our logit and conditional logit specifications. As expected, we find EXPORTS to be positive and statistically significant. More importantly, its inclusion does not affect the significance and magnitude of the trust variable. This suggests that, even after possibly over-specifying the model, we continue to find that trust matters. In fact, the evidence suggests that trust matters more for $\mathrm{VC}$ investment than for aggregate trade flows.

\subsection{Further discussion}

In the online Appendix we discuss several extensions and robustness checks for our results about trust and investment decisions. Here we briefly summarize them. We start by considering several alternative measures of trust. First, we note that the trust of the average citizen and that of a sophisticated investor may differ. We therefore build a measure of trust including only Eurobarometer respondents with socio-economic characteristics that correspond to those of venture investors. Second, we note that entrepreneurs have to accept investors' offers, so that trust from their perspective may also influence the likelihood of a deal. ${ }^{17}$ Third, we compute the trust measure considering the nationalities of all the partners of a given VC. Fourth, we compute a residual measure of trust that removes investor- and company-country averages. Fifth, we compute a measure of trust that considers an alternative ordinal characterization based on the odds ratio. In all these cases our results are unchanged.

\footnotetext{
${ }^{16}$ However, there is also one reason not to include trade. Guiso, Sapienza and Zingales (2009) establish a positive relationship between trust and aggregate trade flows. Including trade in our equation therefore introduces multicollinearity, i.e., the model may be over-specified.

${ }^{17}$ This empirical test corresponds to the conceptual distinction between trusting and trustworthiness (see Glaeser et al. (2000)). Trusting describes a focal person's beliefs about others, whereas trustworthiness describes other's beliefs about the focal person. In our context, the distinction between trusting and trustworthiness corresponds to the distinction between the venture capitalists' trust of entrepreneurs and entrepreneurs' trust of venture capitalists.
} 
In addition, we estimate our model in the alternative dataset from ThomsonOne, which we described in section 2.1 and find very similar results.

We also consider alternative specifications of equation (1). First, in the online Appendix we consider a set of nested logit and conditional logit models to see whether any particular group of controls has a large impact on the estimated trust coefficient. ${ }^{18} \mathrm{We}$ find that the trust coefficient is remarkably stable, in terms of both coefficient magnitude and statistical significance. Second, in order to distinguish between how much investors 'trust' other countries (beliefs) from how much investors 'like' other countries (taste), we add a measure of 'liking between countries' based on the Eurovision Song Contest. Third, we implement two-dimensional clustering (Petersen (2009)) where we cluster both at the company-country and the investor-country level. Fourth, we compute the corresponding minimal distance between each company and investors considering also VC firms' secondary offices. In all these cases our results are unchanged. The online Appendix discusses these and further robustness checks in greater detail.

\section{Trust and investment success}

We now turn to the relationship between trust and investment success. In this section we empirically test Proposition 2, which predicts that higher relative trust is associated with a lower success rate.

\subsection{Main results}

Our unit of analysis is the sample of realized deals. The dependent variables are the three measures of investment outcome that we discussed in section 2.3: (i) IPO, as the main measure of successful investment, (ii) EXIT, which also includes acquisitions, a more frequent but often less profitable exit route, and (iii) FAILURE, which measures unsuccessful venture investments. Our econometric model is given by:

$$
\text { OUTCOME } E_{r}=\alpha+X_{n}^{\prime} \beta^{n}+X_{r}^{\prime} \beta^{r}+X_{i}^{\prime} \beta^{i}+X_{c}^{\prime} \beta^{c}+\varepsilon_{p}
$$

where $r=(i, c)$ indexes the realized investor-company pairs. The $X$ vectors represent the same variables as in equation (1), except for fixed effects. In the realized deals sample we cannot use company fixed effects, as there cannot be any variation of outcomes within a company. There are also pros and cons to using investor fixed effects. The main worry about not using them is to under-control for unobserved investor characteristics. However, the main worry about using them is adding spurious information. Over-controlling is particularly relevant for smaller sample sizes, such as our hand-collected data. In addition, we note that our selection-based theory does not even suggest that it is necessary to control for as many factors as possible. Indeed, adding controls that are correlated with trust could

\footnotetext{
${ }^{18}$ Specifically, to examine the role of investor fixed effects we drop them. We first run a regression that only controls for country fixed effects (company country, investor country and the foreign deal dummy). This provides the minimal levels of control that still retain the concept of relative trust. We then add all the control variables except those that vary at the country-dyadic level. This essentially allows to control for deal characteristics but omits all cross-country variables that might be correlated with trust. Finally we add those country-dyadic variables back in. We then repeat these steps using the conditional logit model which controls for investor fixed effects instead of investor country fixed effects.
} 
obfuscate the true effect. We therefore report several regression models, to get a balanced picture of what factors may or may not affect the relationship between trust and outcomes.

As a first step, let us consider the pairwise correlations between trust and outcomes. From Panel B of the Appendix Correlations Table we note that the correlation coefficient of trust with IPO is -0.105 , with EXIT is -0.101 and with FAILURE is 0.141 . All three coefficients are significant at the $1 \%$ level. This is by itself an important finding: in the absence of any controls, we find strong evidence for a negative relationship between trust and successful outcomes.

Panels A, B, and C of Table 3 report results for IPO, EXIT, and FAILURE, respectively. In each panel we examine four regression models using different sets of control variable. In all models we control for investor-country and company-country fixed effects, thereby ensuring that our trust variable measures relative trust. In the first column we only add the country-dyadic variables. The main objective here is to distinguish trust from the many other factors that affect cross-country investment behavior. In column (ii) we add all remaining variables from equation (2), except for investor controls. In column (iii) we add four investor characteristics that prior research identified as important, namely VC-SIZE, VC-AGE, INDEPENDENT-VC and US-EXPERIENCE. This allows us to control for investor heterogeneity, without over-burdening the model with investor fixed effects. Finally, in column (iv) we use a conditional logit model, which conditions on investor fixed effects, thereby using only within-portfolio variation. The four columns thus represent a broad spectrum of alternative specifications, each with their pros and cons.

In Table 3 we find that the coefficient of trust always has the expected sign, and is significant (or close to significance at the $10 \%$ level) in most regressions. As expected, we find a decline in statistical significance as we add more controls. Interestingly the coefficient values hardly change across the four columns. Overall this suggests a robust negative relationship between trust and success, as predicted by Proposition 2 .

The number of observations changes as we add controls. Of particular concern is the drop-off in column (iv), where the conditional logit can only utilize those VC firms that have variation across investment outcomes. This exposes the limitations of using investor fixed effects, as we lose much valuable information, especially from smaller VC firms. For the remainder of the analysis we mainly focus on the model of column (iii), which arguably strikes a reasonable balance between under- and over-controlling for investor characteristics.

It is worth briefly commenting on the role of the investor characteristics. We note that US-EXPERIENCE and VC-SIZE have a positive and mostly significant impact on outcomes. This is consistent with the prior VC literature which suggests that these measures are correlated with investor quality (see Kaplan and Schoar (2005) and Kaplan, Martel and Strömberg (2007). We may then ask how these quality measures relate to trust. In the online Appendix we derive the theoretical prediction that higher quality investors are more willing to invest in lower trust deals. Empirically we find support for this prediction. Panel B of the Appendix Correlations Table shows a strong negative correlation of TRUST with US-EXPERIENCE and VC-SIZE, both significant at $1 \% .{ }^{19}$

\footnotetext{
${ }^{19}$ We also notice that FOREIGN DEAL has consistently negative, and significant, coefficients, consistent with Chemmanur, Nandy, and Krishnan (2011); DISTANCE also has a similar effect. EARLY STAGE has a negative and significant effect on outcomes, consistent with the findings of Puri and Zarutskie (2012).
} 


\subsection{Testing for selection effects}

The results from Table 3 establish correlation, not causation. Disentangling selection and treatment effects is a ubiquitous challenge in empirical work. Frequently the econometrician wants to purge selection effects from the regression, in order to identify a causal treatment effect. Here our concern is essentially the opposite, as our theory is based on a selection logic. In our model, VCs with higher trust invest relatively more in companies that, based on available information, have relatively lower chances of success. Note that the theory does not specify whether the VC's information is also available to the econometrician. We should therefore consider both observable and unobservable selection effects.

As a first step we look for observable selection effects. For this we correlate trust with several 'prediction indices' that map observable company characteristics into predicted success probabilities. Our goal is to test for selection effects by explicitly relating investor trust to company characteristics that are observable at the time of investing. ${ }^{20}$ Specifically, we build each index as the predicted value from a regression where we regress each outcome measure (IPO, EXIT or FAILURE) on those company characteristics that are observable at the time of funding, namely company country, industry, stage and investment date. We deliberately omit from the regression all investor characteristics, precisely because we are interested in how investors select based on observable company characteristics.

The results are summarized in Panel A of Table 4. Column (i), (ii), and (iii) correspond to the IPO, EXIT, and FAILURE indices, which are the predicted probability of the respective outcome based on observable company characteristics. In the first row we report the pairwise correlation of these indices with our trust measure. We find that all the correlation coefficients have the expected sign, and take on large absolute values, ranging from 0.24 to 0.36 . They are also all significant at $1 \%$. In the second row we repeat the correlation exercise using a measure of 'residual trust' that is obtained from a regression of trust on all investor- and company-country fixed effects, thus removing any correlation due to country-dyadic effects. Again we find very similar results, with absolute values ranging from 0.22 to 0.52 , all significant at $1 \%$. These correlations provide clear evidence of a significant selection effect: higher trust investors invest in companies that, based on observable characteristics, have lower success probabilities. This is consistent with the model prediction in Proposition 2.

As a second step, we consider a Heckman framework, which allows us to take into account unobservable selection effects. Of particular interest to us is the Mills ratio, which estimates the correlation of the unobservable errors. Naturally the Heckman framework also estimates treatment effects. In our discussion of the theory in section 2.5, we saw that our model generates ambiguous predictions about the direction of treatment effects.

To estimate the Heckman model, we use the selection equation from equation (1) and the outcome equation from equation (2). ${ }^{21}$ Identification in the Heckman model requires

\footnotetext{
${ }^{20}$ One implicit assumption of this approach is that investors know how to map observable characteristic into predicted success probabilities. In order to relax this assumption one would need to model investor learning. Unfortunately, estimating such dynamic learning processes would require much long time series, and is beyond the scope of this paper.

${ }^{21}$ Note that because of the large number of observations (over 100,000 in the selection equation) and control variables, we can only achieve convergence in STATA when we use the linear probability version (heckman instead of heckprob), and invoke the two-step estimation procedure (which still achieves
} 
an exclusion restriction that can only be asserted, but not proven. The challenge is to augment the selection equation with variables that affect the selection equation, but that can reasonably be excluded from the outcome equation. We suggest EXPORTS as a plausible candidate. ${ }^{22}$ Our rationale is that a high level of exports means that two countries are likely to have well-established networks for facilitating cross-country commercial transactions. Rauch (2001), for example, suggests that trade flows are related to interpersonal networks. We argue that the presence of such institutional links facilitate the matching process between entrepreneurs and investors, as we found in Table 2. However, once the match is made, it is reasonable to assume that these trade-related institutional links no longer have a direct impact on investment success.

Panel B of Table 4 reports the estimates for the Heckman model. Consistent with the results from Table 2, we find again that EXPORTS is highly significant with the expected sign. Our main focus is the unobservable selection effect, as measured by the Mills ratio. In columns (i) and (ii), the Mills ratio is negative and significant (with pvalues of 0.011 and 0.92 , respectively). This suggests that there is a negative correlation between unobservable factors that encourage investment and factors that reduce the IPO and EXIT rates, consistent with our theory. In column (iii) the Mills ratio for FAILURE is not statistically significant, although it still has the sign predicted by our theory.

In the outcome equation we note that the coefficient of trust is negative and significant for IPO, insignificant for EXIT, and positive and significant for FAILURE. If we interpret these treatment effects as the effect of trust of VCs value-adding efforts, then the empirical estimates suggest that higher trust is on average associated with lower VC efforts. This suggests that of the two effects discussed in section 1.2, the negative effect is the stronger one.

\subsection{Further discussion}

We briefly summarize here several extensions and robustness checks that we discuss in the online Appendix in greater detail. Similar to section 3, we consider several alternative measures of trust: the socio-economic measure, trust from the company perspective, trust measured accounting for the nationality of individual VC partners, the odds-ratio transformation of trust, and residual trust. Some VCs may have multiple office, so we also consider the distance between a company and the closest investor office. We also reestimate the model in the alternative dataset from ThomsonOne, and find that the results remain broadly consistent.

We then include some robustness checks specific to the investment outcome regressions. For example, for the few companies with multiple deals we keep the earliest and delete all others. This does not affect any results. And we re-estimate the Heckman model of Panel B of Table 4 replacing EXPORTS with FDI, again with no qualitative changes in our results.

We also examine the relationship of trust and exit values. Our main analysis focuses on the probability of exit as our key dependent variable. One may ask if the same relationship pertains to the exit value in case of success. A particular concern might be that higher trust investments could have higher exit values. This would mean that lower trust investments

consistent estimates)

${ }^{22}$ We obtain the same results if we replace EXPORTS with FDI. We discuss this further in the appendix. 
pertain not to 'better' companies (in a first order stochastic dominance sense), but to less risky companies (in a second order stochastic dominance sense). To examine this we gather data on exit values. In case of IPOs we use the natural logarithm of the market capitalization; in case of acquisitions, we use the natural logarithm of the transaction value, and drop the observation if the value is undisclosed; in case of failure we either drop the observations (resulting in a variable called EXIT VALUE), or we set the value to zero (resulting in a variable called EXIT PERFORMANCE). Despite the apparent data limitations, these two variables still contain valuable information. The first gauges the exit value in case of success; the second provides a performance proxy that captures information both about whether companies have an exit, and the value in case of exit.

We first examine the pairwise correlation of these two measures with trust. We find that EXIT VALUE and TRUST have a negative correlation of -0.02 (p-value of 0.02 ), and that EXIT PERFORMANCE and TRUST have a negative correlation of -0.21 (p-value of 0.00). This suggests that there is a small negative correlation between exit values and trust. The relationship becomes much stronger when we look at the broader performance measure, which is consistent with our main findings. In the online Appendix we report the results of OLS regressions models with the same specification of Table 3. For EXIT VALUE we find a small negative coefficient that is statistically insignificant, for EXIT PERFORMANCE the coefficient is much larger and statistically significant at $5 \%$. Because EXIT PERFORMANCE has a mass point at its lower bound of zero, we also estimate a Tobit model and find that trust is negative and significant at $1 \%$. The concern about lower trust being associated with lower risk thus do not seem to be supported by the available data. The main finding about a negative relationship between trust and success appears robust to the inclusion of exit values. ${ }^{23}$

\section{Trust and deal structure}

In this section we empirically test the predictions of the model concerning the effects of trust on investment deal structures.

\subsection{Investment stage}

Proposition 3 predicts that investing in earlier stages requires more trust. To test this, we consider the stage at which a company is receiving financing. EARLY STAGE is a dummy that takes value 1 if the deal is done at seed or start-up stage, and 0 if the deal is done at late or bridge stage. We use a regression framework to estimate conditional correlation coefficients. Obviously these regressions are only meant to establish correlation, not causation.

In column (i) of Table 5 we report results from a logit regression where EARLY STAGE is the dependent variable, and the specification is the same as in columns (i) of Table 3,

\footnotetext{
${ }^{23}$ It is worth noting that in our theory expected returns are characterized by $\pi x$. For the main analysis we focus on distributions of $\pi$, holding $x$ constant. Given the simple multiplicative structure of $\pi x$, the model can easily be altered to focus on distributions of $x$. We only need an assumption that the focal investor faces a different distribution of exit values than the competitive fringe (analogous to the difference between $\pi$ and $p$ ). With that, we can directly apply the logic of Proposition 2 to generate a prediction of a negative relationship between trust and exit values.
} 
therefore including investor-country, company-country, and all country-dyadic controls (clearly without the early stage control itself). In column (ii) of Table 5 we add the investor-company dyadic controls, as in column (ii) of Table 3 (again omitting the early stage control itself). In columns (iii) and (iv) we go back to our raw data to decompose our stage variable into four stages: seed, early, late and bridge. We estimate ordered logit models for STAGE (with later stages taking on larger values), using the same controls as in columns (i) and (ii). We find that TRUST is always positive and significant in all specifications but the first. These results are supportive of the predictions of Proposition 3.

\subsection{Syndication}

Proposition 4 predicts that VCs are more likely to bring syndication partners into deals where trust is low. To test this, we build SYNDICATION as a dummy that takes value 1 if the deal involves more than one investor, and 0 otherwise. Again we use regression analysis to examine conditional correlations.

Column (i) of Table 6 shows the results from a logit regression where the dependent variable is SYNDICATION. The regression estimates the effect of trust, controlling for investor-country, company-country, and all country-dyadic controls, as in column (i) of Table 3. In column (ii) we further add all the investor-company dyadic controls, as in column (iii) of Table 3. In both columns, we find a negative and significant coefficient for trust, significant at the $5 \%$ confidence level. This empirically validates the model prediction of Proposition 4.

\subsection{Contingent contracts}

Proposition 5 predicts a positive relationship between trust and the use of contingent contracting clauses. We consider that venture capital contracts often include clauses that grant investors certain rights that depend (are contingent) on the company's performance. Consequently, we build from our survey data four dummy variables that take value 1 if a given contingent clause is included in the financing contract, and 0 otherwise. The clauses are: whether the investor has the right to acquire a board seat (CC-BOARD), the right to increase the investor's voting rights (CC-VOTING), the right to liquidate the company (CC-LIQUIDATION), and the right to fire the CEO (CC-TERMINATION). We then aggregate these dummies in an index measure that sums them up, and that can take values from 0 to 4 (CC-INDEX).

Panel $\mathrm{C}$ of the Appendix Correlations Table shows pairwise correlations between the contingent contracting measures and trust. We find that trust is positively and significantly related to all these measures. Table 7 reports the results from regressions about the effect of trust, again using the same specification as in column (iii) of Table 3. In column (i) the dependent variable is the index of all contingent control variables. We use an ordered logit model. The effect of trust is positive and significant at the $5 \%$ confidence level. In columns (ii) to (v) we use the individual components of the index, and we use logit models. Trust is significant in two out of four regressions, with p-values of 0.001 and 0.062 . This evidence supports the theoretical prediction of Proposition 5. 


\subsection{Further discussion}

Also for this section we briefly summarize several extensions and robustness checks that we discuss in the online Appendix in greater detail. Similar to the previous sections, we consider several alternative measures of trust: the socio-economic measure, trust from the company perspective, trust measured accounting for the nationality of individual VC partners, residual trust, and the odds-ratio measure of trust.

We consider using company age as an alternative measure to EARLY STAGE. While we have fewer observations for company age, we still find a negative relationship between trust and company age, consistent with Proposition 3.

We also estimate conditional logit models for EARLY-STAGE and SYNDICATION with similar results. For the contingent contracts regressions we are unable to obtain convergence in the conditional logit model. However, in the Heckman regressions we find very similar results to those reported in Table 7 .

\section{Conclusion}

We examine the effect of generalized trust on venture capital investments and outcomes. The venture industry provides an attractive testing ground for the effects of trust. One can reasonably argue that venture capital investors are sophisticated investors who would not act upon poorly-informed priors, and who are well positioned to exploit any arbitrage opportunities. At the same time, one might counter that the financing of new companies inherently involves limited hard information, high uncertainty, and considerable scope for opportunistic behavior. Investors can therefore be more prone to rely on soft information, including social beliefs such as trust.

Our paper contributes to understanding the role of trust for corporate financial transactions. First, we are able to identify an effect of trust on investments in a micro-economic environment where alternative explanations can be controlled, most notably with investor and company fixed effects. Second, our analysis derives results about the relationship between generalized trust and investment success, which are new to the corporate finance literature. Our evidence suggests that lack of trust imposes a hurdle for investments, as suggested by the negative relationship between trust and exits. Third, our paper uncovers and explains some novel relationships between trust and investment deal structures. Overall this paper establishes that generalized trust is a force that cannot be ignored in the analysis of venture capital investment. This opens the door for further research on the importance of trust for financial transactions.

Our analysis also has some implications for policy. Governments across the globe are seeking to attract venture capital investors to invest in their countries. ${ }^{24}$ Our results suggest that investments might be more forthcoming from countries where there is higher generalized trust. This provides some guidance as to what countries might be the most promising targets for governments that want to attract foreign venture capitalists to their countries.

\footnotetext{
${ }^{24}$ See Bottazzi and Da Rin (2002), Da Rin, Nicodano, and Sembenelli (2006) and Lerner (2008).
} 


\section{References}

[1] Ahern, Kenneth, Danielle Daminelli, and Cesare Fracassi (2015) 'Lost in Translation? The Effect of Cultural Values on Mergers around the World,' Journal of Financial Economics, 117 (1), 165-189.

[2] Arrow, Kenneth (1973) 'The Theory of Discrimination,' in Orley Aschenfelter and Albert Rees (eds.) Discrimination in Labor Markets, Princeton, Princeton University Press.

[3] Bae, Kee-Hong, René Stulz, and Hongping Tan (2008) 'Do Local Analysts Know More? A Cross-country Study of the Performance of Local Analysts and Foreign Analysts,' Journal of Financial Economics, 88 (3), 581-606.

[4] Balcarcel, Ana, Michael Hertzel, and Laura Lindsey (2010) 'Contracting Frictions and Cross-Border Capital Flows: Evidence from Venture Capital,' Mimeo.

[5] Bengtsson, Ola, and David Hsu (2010) 'How Do Venture Capital Partners Match with Startup Founders?' Mimeo, Wharton School.

[6] Bloom, Nicholas, Raffaella Sadun, John Van Reenen (2012) 'The Organization Of Firms Across Countries,' Quarterly Journal of Economics, 127 (4), 1663-1705.

[7] Bottazzi, Laura, and Marco Da Rin (2002) 'Venture Capital in Europe: Euro.nm and the Financing of European Innovative Firms,' Economic Policy, 17 (1), 229-269.

[8] Bottazzi, Laura, Marco Da Rin, and Thomas Hellmann (2008) 'Who are the Active Investors? Evidence from Venture Capital,' Journal of Financial Economics, 89 (3), 488-512.

[9] Bottazzi, Laura, Marco Da Rin, and Thomas Hellmann (2009) 'What is the Role of Legal Systems in Financial Intermediation? Theory and evidence,' Journal of Financial Intermediation, 18 (4), 559-598.

[10] Bottazzi, Laura, Paolo Pesenti, and Eric van Wincoop (1996) 'Wages, Profits, and the International Portfolio Puzzle,' European Economic Review, 40 (2), 219-254.

[11] Brander, James, Raphael Amit, and Werner Antweiler (2000) 'Venture-Capital Syndication: Improved Venture Selection vs. the Value-Added Hypothesis' Journal of Economics and Management Strategy, 11, (3), 423-452.

[12] Chemmanur, Thomas, Tyler Hull, and Karthik Krishnan (2011) 'Do Local and International Venture Capitalists Play Well Together? A Study of International Venture Capital Investments,' Mimeo.

[13] Cumming, Douglas, Daniel Schmidt, and Uwe Walz (2010) 'Legality and Venture Finance Around the World,' Journal of Business Venturing, 25 (1), p.54-72.

[14] Da Rin, Marco, Thomas Hellmann, and Manju Puri (2013), 'A Survey of Venture Capital Research,' in George Constantinides, Milton Harris, and René Stulz (eds.) Handbook of the Economics of Finance, volume 2, Amsterdam, North Holland, 573648. 
[15] Da Rin, Marco, Giovanna Nicondano, and Alessandro Sembenelli (2006) 'Public Policy and the Creation of Active Venture Capital Markets,' Journal of Public Economics, 80 (8-9), 1699-1723.

[16] Durlauf, Steven and Marcel Fafchamps (2006) 'Social Capital,' in Steven Durlauf and Philippe Aghion (eds.) Handbook of Economic Growth, Amsterdam, Elsevier.

[17] Ekinci, Mehmet, Sebnem Kalemli-Ozcan, and Bent Sorensen, (2007) 'Financial Integration within EU Countries: The Role of Institutions, Confidence and Trust,' in NBER International Seminar on Macroeconomics 2007, Cambridge, National Bureau of Economic Research.

[18] French, Kenneth, and James Poterba (1991) 'Investor Diversification and International Equity Markets,' American Economic Review, 81 (2), 222-226.

[19] Glaeser, Edward, David Laibson, José Scheinkman, and Christine Soutter (2000) 'Measuring Trust,' Quarterly Journal of Economics, 115 (3), 811-846.

[20] Graham, John, and Campbell Harvey (2001) 'The Theory and Practice of Corporate Finance: Evidence from the Field,' Journal of Financial Economics, 60 (1), 187-243.

[21] Granovetter, Mark (1995) Getting a Job: A Study of Contacts and Careers, Chicago, University of Chicago Press.

[22] Greif, Avner (1993) 'Contract Enforceability and Economic Institutions in Early Trade: The Maghribi Traders' Coalition,' American Economic Review, 83 (3), 525548.

[23] Guiso, Luigi, Paola Sapienza, and Luigi Zingales (2006) 'Does culture affect economic outcomes?' Journal of Economic Perspectives, 20 (2), 23-48.

[24] Guiso, Luigi, Paola Sapienza and Luigi Zingales (2008) 'Trusting the Stock Market,' Journal of Finance, 63 (6), 2557-2600.

[25] Guiso, Luigi, Paola Sapienza, and Luigi Zingales (2009) 'Cultural Biases in Economic Exchange,' Quarterly Journal of Economics, 124 (3), 1095-1131.

[26] Head, Keith and Thierry Mayer (2010) 'Illusory Border Effects: Distance Mismeasurement Inflates Estimates of Home Bias in Trade' in Brakman, Steven and Peter van Bergeijk (eds.) The Gravity Model in International Trade: Advances and Applications, Cambridge, Cambridge University Press.

[27] Hegde, Deepak and Justin Tumlinson (2014) 'Does Social Proximity Enhance Business Partnerships? Theory and Evidence from Ethnicity's Role in US Venture Capital,' Management Science, 60 (9), 2355-2380.

[28] Hellmann, Thomas (2006) 'IPOs, Acquisitions and the Use of Convertible Securities in Venture Capital,' Journal of Financial Economics, 81 (3), 649-679.

[29] Hellmann, Thomas, and Manju Puri (2002) 'Venture Capital and the Professionalization of Start-ups: Empirical Evidence,' Journal of Finance, 57 (1), 169-97. 
[30] Hochberg, Yael, Alexander Ljungqvist, and Yang Lu (2007) 'Whom you Know Matters: Venture Capital Networks and Investment Performance,' Journal of Finance, 62 (1), 251-301.

[31] Kaplan Steven, Frederic Martel and Per Strömberg (2007) 'How Do Legal Differences and Learning Affect Financial Contracts?' Journal of Financial Intermediation, 16 (4), 273-311.

[32] Kaplan, Steven, and Per Strömberg (2003) 'Financial Contracting Theory Meets the Real World: An Empirical Analysis of Venture Capital Contracts,' Review of Economic Studies, 70 (2) 281-315.

[33] Kaplan, Steven, and Per Strömberg (2004). 'Characteristics, Contracts, and Actions: Evidence from Venture Capitalist Analyses,' Journal of Finance, 59, 2177-2210.

[34] Kaplan, Steven, and Antoinette Schoar (2005). 'Private Equity Performance: Returns, Persistence, and Capital Flows,' Journal of Finance, 60 (4), 1791-1823.

[35] Karolyi, Andrew, and René Stulz (2003) 'Are Assets Priced Locally or Globally?' in George Constantinides, Milton Harris and René Stulz (eds.), The Handbook of the Economics of Finance, Amsterdam, North Holland.

[36] Knack, Stephen and Keefer Philip (1997) 'Does Social Capital Have an Economic Payoff? A Cross-Country Investigation,' Quarterly Journal of Economics, 112 (4), $1251-1288$.

[37] Lerner, Josh (2008) Boulevard Of Broken Dreams: Why Public Efforts To Boost Entrepreneurship And Venture Capital Have Failed, Princeton University Press, Princeton.

[38] Lerner, Josh, and Antoinette Schoar (2005) 'Does Legal Enforcement Affect Financial Transactions? The Contractual Channel in Private Equity,' Quarterly Journal of Economics 120 (1), 223-246.

[39] McFadden, Daniel (1984)'Econometric Analysis of Qualitative Response Models,' in Zvi Griliches and Michael Intrilligator (eds.) Handbook of Econometrics, vol.2, Elsevier, Amsterdam.

[40] Möllering, Guido (2006) Trust : Reason, Routine, Reflexivity, Amsterdam, Elsevier.

[41] Morris, Stephen (1995) 'The Common Prior Assumption in Economic Theory,' Economics and Philosophy, 11 (1), 227-53.

[42] Nooteboom, Bart (2002) Trust: Forms, Foundations, Functions, Failures and Figures, Cheltenham, Edward Elgar.

[43] Petersen, Mitchell (2009) 'Estimating Standard Errors in Finance Panel Data Sets: Comparing Approaches', Review of Financial Studies, 22 (1), 435-480.

[44] Phalippou, Ludovic, and Oliver Gottschalk (2009), 'The performance of private equity funds,' Review of Financial Studies, 22 (4), 1747-1776. 
[45] Puri, Manju, and Rebecca Zarutskie (2012) 'On the Life Cycle Dynamics of VentureCapital and Non-Venture-Capital-Financed Firms,' Journal of Finance, 67 (6), 27472293.

[46] Rauch, James (2001) 'Business and Social Networks in International Trade', Journal of Economic Literature, 39 (4)), 1177-1203

[47] Sørensen, Morten (2007) 'How Smart is Smart Money? An Empirical Two-Sided Matching Model of Venture Capital,' Journal of Finance, 62 (6), 2725-2762.

[48] Sorenson, Olav, and Toby Stuart (2001) 'Syndication Networks and the Spatial Distribution of Venture Capital Investments, American Journal of Sociology, 106 (5), $1546-1588$.

[49] Temple, Jonathan, and Paul Johnson (1998) 'Social Capability and Economic Growth,' The Quarterly Journal of Economics, 113 (3), 965-990.

[50] Tyebjee Tyzoon, and Albert Bruno (1984) 'A Model of Venture Capitalist Investment Activity,' Management Science, 30 (9), 1051-1066.

[51] Zak, Paul, and Stephen Knack (2001) 'Trust and Growth,' Economic Journal, 111, 295-321. 


\section{Table 1: Variable definitions \\ Panel A: Dependent variables}

Deal is measured at the potential deal level. All other dependent variables are measured at the (realized) deal level. Early Stage, which is used as control in the realized deal regressions, is defined in Panel C.

VARIABLE $\quad$ DESCRIPTION

DEAL

IPO

EXIT

FAILURE

SYNDICATION

STAGE

SYNDICATION

CONTINGENT

CONTRACTS (CC)

$\operatorname{Pr}(\mathrm{IPO})$

$\operatorname{Pr}($ EXIT)

$\operatorname{Pr}($ FAILURE)

CC-BOARD

CC-VOTING

CC-LIQUIDATION

CC-TERMINATION dummy variable that takes the value 1 if the venture capital firm has invested in a particular company; 0 otherwise. We obtain the data from our survey instrument, which asked venture firms to list all their portfolio companies.

dummy variable that takes the value 1 if the company has been exited by October 2011 via an Initial Public Offering ; 0 otherwise. The data is obtained from the Amadeus, Zephyr, and SDC Platinum databases, and from web searches.

dummy variable that takes the value 1 if the company has been exited by October 2011 via an IPO or acquisition; 0 otherwise. The data is obtained from the Amadeus, Zephyr, and SDC Platinum databases, and from web searches.

dummy variable that takes the value 1 if by October 2011 the company had gone out of business or could not be traced; 0 otherwise. The data is obtained from the Amadeus, Zephyr, and SDC Platinum databases, and from web searches.

dummy variable that takes the value 1 if the deal is by October 2011 the company had gone out of business or could not be traced; 0 otherwise. The data is obtained from the Amadeus, Zephyr, and SDC Platinum databases, and from web searches.

categorical variable for the stage at which the company raised venture finance. It takes values from 1 to 4 corresponding to the four possible stages: seed, start-up, expanstion, and bridge. We obtain the data from our survey instrument, which asked: Indicate the type of your first round of financing to this company. Possible answers were: Seed; Start-up; Expansion; Bridge.

dummy variable that takes value 1 if the deals involves more than one investor; 0 otherwise. We obtain the data from our survey instrument, which asked: Were you the only investor in this deal? Possible answers were: Yes; No.

index measure of contingent control rights obtained from counting the presence of the following four contingent control rights: control over the board of directors, voting rights, company liquidation, and termination of the founder's employment contract. This variable takes a value between 0 and 4 . We obtain the data from our survey instrument, see the definition of the four dummies below.

set of predicted probabilities for the outcome events IPO, EXIT, and PROBABILITY, obtained regressing the outcome on the available information at the time of the deal (date, stage, sector, and country.

set of four dummy variables that take the value 1 if the financing deals grants the investor the specified contingent control right; 0 otherwise. We obtain the data from our survey instrument, which asked the following questions: Does your firm has a right to obtain control of the board of directors contingent on the realization of certain events? Does your firm has a right to obtain voting rights contingent on the realization of certain events? Does your firm has a right to liquidate the company contingent on the realization of certain events? Does your firm has a right to fire the founder/CEO contingent on the realization of certain events? For all questions, possible answers were: $Y e s, N o$. 


\section{Panel B: Independent country-dyadic variables}

Country-dyadic variables are measured at the level of the investor-country and company-country pair.

\begin{tabular}{ll}
\hline \hline VARIABLE & DESCRIPTION \\
\hline
\end{tabular}

TRUST

RESIDUAL TRUST

INFORMATION

GDP DIFFERENCE

LANGUAGE OVERLAP

LEGAL DIFFERENCE

FOREIGN DEAL

COMMON BORDER

EXPORTS percentage of the citizens in one contry that trust a lot people from the other country. It is obtained from the Eurostat's Eurobarometer question: "I would like to ask you a question about how much trust you have in people from various countries. For each, please tell me whether you have a lot of trust, some trust, not very much trust or no trust at all." The answers range from 1 (no trust at all) to 4 (a lot of trust). Our measure is the percentage of individuals who respond 4.

measure of trust obtained by regressing trust on investor- and company-country dummies.

percentage of times a country is mentioned in the other country's main business newspaper over the 1998-2001 period, obtained from the Factiva database. For each country dyad, we record the number of articles in the main business newspaper of country $i$ that mention in the headlines country $j$, or citizens of country $j$. We divide this number by the total number of articles in the newspaper that are related to all the countries in our sample. We set INFORMATION equal to zero for domestic deals $(i=j)$.

difference (for each country pair) of the log-transformed per capita GDP, expressed in euros and averaged over the 1998-2001 period. This variable is obtained from Datastream.

percentage of people who speak the same language in each country dyad. This variable is set to 1 for domestic deals. The data is obtained from www.ethnologue.com.

dummy variable that takes value 1 if investor and company are located in countries with different legal origins; 0 otherwise. We distinguish between Common law, French-origin civil law, German-origin civil law, and Scandinavian-origin civil law. The data is obtained from La Porta et al. (1998).

dummy variable that takes value 1 if the investor and company are from different countries; 0 otherwise.

dummy variable that takes value 1 if the investor's and company's countries share a land border; 0 otherwise (including domestic deals).

percentage of the exports from country $i$ to country $\mathrm{j}$, out of the total export towards the sample countries, averaged over the period from 1998 to 2001. This variable is set to 0 for domestic deals. The data is obtained from the UN World Trade database. 


\section{Panel C: Other independent variables}

Distance, Industry Fit, and Stage Fit are measured at the investor-company pair level; Independent VC, VC Size, VC Age, and VC US Experience and investor (country) fixed effects are measured at the investor level; all other variables are measured at the deal level.

\begin{tabular}{ll}
\hline \hline VARIABLE & DESCRIPTION \\
\hline DISTANCE & natural logarithm of one plus the kilometric distance between the venture cap- \\
& ital investor and the company. The distance is computed by applying the geo- \\
& detic formula to the longitudinal and latitudinal coordinates of each investor \\
& and company pair. This data is obtained from www.multimap.com.
\end{tabular}

\section{INDUSTRY FIT}

\section{STAGE FIT}

\section{INDEPENDENT VC}

VC SIZE

VC AGE.

VC US EXPERIENCE

INDUSTRY

EARLY STAGE

DEAL DATE

INVESTOR F.E.

INVESTOR COUNTRY F.E. set of investor country dummy variables.

COMPANY COUNTRY F.E. set of company country dummy variables. percentage of the deals made by the venture capital investor in the same industry of the company.

percentage of the deals made by the venture capital investor in the same stage at which the company gets financed.

dummy variable that takes the value 1 if the venture capitalist defines itself as an independent venture firm; 0 otherwise

natural logarithm of one plus the amount under management of the venture capital firm at the end of the sample period, in millions of current euros.

natural logarithm of one plus the age of the venture capital firm, measured in months at the end of the sample period.

dummy variables that takes value 1 if a venture capital investor has partners with US work experience; 0 otherwise. We obtain the data from our survey instrument, which asked, for each partner: Has this partner work experience in the US? Possible answers were: Yes; No.

set of dummy variables for each company's industry. We obtain the data from our survey instrument, which gave the following choices: Biotech and pharmaceuticals; Medical products; Software and internet; Financial services; Industrial services; Electronics; Consumer services; Telecommunications; Food and consumer goods; Industrial products (including energy); Media \& Entertainment; Other.

dummy variable that takes value 1 if the company raised seed or start-up finance; 0 otherwise. We obtain the data from our survey instrument, which asked: Indicate the type of your first round of financing to this company. Possible answers were: Seed; Start-up; Expansion; Bridge.

set of dummies for the year of the deal.

set of 107 dummy variables, one for each investor. 


\section{Table 2}

\section{Deal regressions}

This table reports results of logit and conditional logit regressions for the potential deals sample. Variables are defined in Table 1. The dependent variable is DEAL. All regressions include investor fixed effects. Company controls are a set of dummies for each company's country, industry and stage, and for the year the deal was completed. Columns (i) and (iii) report results of logit regressions. Columns (ii) and (iv) report results of conditional logit regressions. These models are discussed in Section 3.1. For each independent variable, we report the estimated coefficient and the z-score (in parenthesis) computed using (Huber-White) heteroskedasticityrobust standard errors. In the logit regressions, standard errors are clustered by country-dyad. Values significant at the $1 \%, 5 \%$ and $10 \%$ level are identified by $* * *, * *, *$.

\begin{tabular}{|c|c|c|c|c|}
\hline & $\begin{array}{c}\text { (i) } \\
\text { DEAL } \\
\text { Logit }\end{array}$ & $\begin{array}{c}\text { (ii) } \\
\text { DEAL } \\
\text { Cond. Logit }\end{array}$ & $\begin{array}{c}\text { (iii) } \\
\text { DEAL } \\
\text { Logit }\end{array}$ & $\begin{array}{c}\text { (iv) } \\
\text { DEAL } \\
\text { Cond. Logit }\end{array}$ \\
\hline Trust & $\begin{array}{r}6.498^{* * *} \\
(3.490)\end{array}$ & $\begin{array}{r}6.484^{* * *} \\
(3.917)\end{array}$ & $\begin{array}{r}5.080^{* * *} \\
(2.800)\end{array}$ & $\begin{array}{r}5.102^{* * *} \\
(2.918)\end{array}$ \\
\hline Exports & & & $\begin{array}{r}11.494^{* * *} \\
(3.587)\end{array}$ & $\begin{array}{r}11.254^{* * *} \\
(3.363)\end{array}$ \\
\hline Information & $\begin{array}{r}4.122^{* * *} \\
(3.245)\end{array}$ & $\begin{array}{r}4.087^{* * *} \\
(3.120)\end{array}$ & $\begin{array}{r}2.376^{* *} \\
(2.008)\end{array}$ & $\begin{array}{c}2.376^{*} \\
(1.873)\end{array}$ \\
\hline GDP Difference & $\begin{array}{c}-4.594^{* *} \\
(-2.495)\end{array}$ & $\begin{array}{r}-4.431^{* * *} \\
(-2.597)\end{array}$ & $\begin{array}{r}-5.570^{* * *} \\
(-3.206)\end{array}$ & $\begin{array}{r}-5.393^{* * *} \\
(-3.244)\end{array}$ \\
\hline Language Overlap & $\begin{array}{r}0.680 \\
(1.491)\end{array}$ & $\begin{array}{r}0.666 \\
(1.160)\end{array}$ & $\begin{array}{r}-0.767 \\
(-1.145)\end{array}$ & $\begin{array}{r}-0.753 \\
(-0.948)\end{array}$ \\
\hline Legal Difference & $\begin{array}{r}-0.174 \\
(-0.579)\end{array}$ & $\begin{array}{r}-0.159 \\
(-0.507)\end{array}$ & $\begin{array}{r}-0.055 \\
(-0.192)\end{array}$ & $\begin{array}{r}-0.043 \\
(-0.139)\end{array}$ \\
\hline Distance & $\begin{array}{r}-0.223^{* *} \\
(-2.574)\end{array}$ & $\begin{array}{r}-0.219^{* * *} \\
(-5.529)\end{array}$ & $\begin{array}{r}-0.219^{* *} \\
(-2.516)\end{array}$ & $\begin{array}{r}-0.215^{* * *} \\
(-5.387)\end{array}$ \\
\hline Foreign Deal & $\begin{array}{r}-1.699 * * \\
(-2.072)\end{array}$ & $\begin{array}{r}-1.685^{* *} \\
(-2.093)\end{array}$ & $\begin{array}{r}-4.489 * * * \\
(-3.690)\end{array}$ & $\begin{array}{r}-4.415^{* * *} \\
(-3.464)\end{array}$ \\
\hline Common Border & $\begin{array}{r}-0.249 \\
(-0.893)\end{array}$ & $\begin{array}{r}-0.254 \\
(-0.838)\end{array}$ & $\begin{array}{r}-0.802^{* *} \\
(-2.276)\end{array}$ & $\begin{array}{r}-0.796^{* *} \\
(-2.190)\end{array}$ \\
\hline Industry Fit & $\begin{array}{r}6.930^{* * *} \\
(27.717)\end{array}$ & $\begin{array}{r}6.838^{* * *} \\
(25.123)\end{array}$ & $\begin{array}{r}6.978^{* * *} \\
(27.607)\end{array}$ & $\begin{array}{r}6.883^{* * *} \\
(24.781)\end{array}$ \\
\hline Stage Fit & $\begin{array}{r}2.976^{* * *} \\
(13.906)\end{array}$ & $\begin{array}{r}2.941^{* * *} \\
(17.532)\end{array}$ & $\begin{array}{r}2.977^{* * *} \\
(13.870)\end{array}$ & $\begin{array}{r}2.941^{* * *} \\
(17.399)\end{array}$ \\
\hline Investor Fixed Effects & Yes & Yes & Yes & Yes \\
\hline Company Controls & Yes & Yes & Yes & Yes \\
\hline Observations & 101,620 & 101,620 & 101,620 & 101,620 \\
\hline Pseudo $R^{2}$ & 0.507 & & 0.510 & \\
\hline Wald $\chi^{2}(42)$ & & 4,032 & & 4,882 \\
\hline Number of Investors & 107 & 107 & $10^{r}$ & 107 \\
\hline Number of Companies & 1,170 & 1,170 & 1,170 & 1,170 \\
\hline
\end{tabular}




\section{Table 3}

\section{Outcome regressions}

This table reports results of regressions for the realized deals sample. Variables are defined in Table 1. The dependent variables in Panels A, B, and C, are IPO, EXIT, and FAILURE, respectively. In each Panel columns (i) to (iii) report results of logit regressions, and column (iv) reports results of conditional logit regresssions. These models are discussed in Section 4.1. For each independent variable, we report the estimated coefficient and the z-score (in parenthesis) computed using (Huber-White) heteroskedasticity-robust standard errors, clustered by country-dyad. Values significant at the $1 \%, 5 \%$ and $10 \%$ level are identified by $* * *, * *, *$.

Panel A: IPO

\begin{tabular}{|c|c|c|c|c|}
\hline & $\begin{array}{c}\text { (i) } \\
\text { IPO } \\
\text { Logit }\end{array}$ & $\begin{array}{c}\text { (ii) } \\
\text { IPO } \\
\text { Logit }\end{array}$ & $\begin{array}{c}\text { (iii) } \\
\text { IPO } \\
\text { Logit }\end{array}$ & $\begin{array}{c}\text { (iv) } \\
\text { IPO } \\
\text { Cond. Logit }\end{array}$ \\
\hline Trust & $\begin{array}{r}-15.779 * * \\
(-2.346)\end{array}$ & $\begin{array}{r}-14.930^{*} \\
(-1.727)\end{array}$ & $\begin{array}{r}-15.947^{*} \\
(-1.668)\end{array}$ & $\begin{array}{l}-14.917 \\
(-1.550)\end{array}$ \\
\hline Information & $\begin{array}{r}-2.848 \\
(-0.605)\end{array}$ & $\begin{array}{r}-3.673 \\
(-0.745)\end{array}$ & $\begin{array}{r}-4.170 \\
(-0.850)\end{array}$ & $\begin{array}{r}-4.584 \\
(-0.913)\end{array}$ \\
\hline GDP Difference & $\begin{array}{r}-4.840 \\
(-0.644)\end{array}$ & $\begin{array}{r}-2.710 \\
(-0.346)\end{array}$ & $\begin{array}{r}-3.125 \\
(-0.397)\end{array}$ & $\begin{array}{r}-5.377 \\
(-0.743)\end{array}$ \\
\hline Language Overlap & $\begin{array}{r}-4.521^{* * *} \\
(-2.803)\end{array}$ & $\begin{array}{r}-3.713^{* *} \\
(-1.989)\end{array}$ & $\begin{array}{r}-4.232^{* *} \\
(-2.037)\end{array}$ & $\begin{array}{r}-6.164 \\
(-1.331)\end{array}$ \\
\hline Legal Difference & $\begin{array}{r}0.460 \\
(0.387)\end{array}$ & $\begin{array}{r}-0.076 \\
(-0.089)\end{array}$ & $\begin{array}{r}0.284 \\
(0.317)\end{array}$ & $\begin{array}{r}0.306 \\
(0.269)\end{array}$ \\
\hline Distance & & $\begin{array}{l}-0.096^{*} \\
(-1.917)\end{array}$ & $\begin{array}{r}-0.100^{* *} \\
(-2.249)\end{array}$ & $\begin{array}{r}-0.132^{* * *} \\
(-2.613)\end{array}$ \\
\hline Foreign Deal & $\begin{array}{r}-8.374^{* * *} \\
(-3.085)\end{array}$ & $\begin{array}{r}-7.334^{* *} \\
(-2.460)\end{array}$ & $\begin{array}{r}-8.499^{* * *} \\
(-2.677)\end{array}$ & $\begin{array}{r}-10.282^{* *} \\
(-2.022)\end{array}$ \\
\hline Common Border & $\begin{array}{r}0.946 \\
(0.872)\end{array}$ & $\begin{array}{r}1.166 \\
(1.069)\end{array}$ & $\begin{array}{r}1.343 \\
(1.098)\end{array}$ & $\begin{array}{r}1.660 \\
(1.482)\end{array}$ \\
\hline Early Stage & & $\begin{array}{r}-1.370^{* * *} \\
(-7.582)\end{array}$ & $\begin{array}{r}-1.339 * * * \\
(-7.329)\end{array}$ & $\begin{array}{r}-1.190^{* * *} \\
(-3.665)\end{array}$ \\
\hline Industry Fit & & $\begin{array}{r}0.275 \\
(0.478)\end{array}$ & $\begin{array}{r}0.035 \\
(0.077)\end{array}$ & $\begin{array}{r}1.579 \\
(1.599)\end{array}$ \\
\hline Stage Fit & & $\begin{array}{r}0.337 \\
(0.596)\end{array}$ & $\begin{array}{r}0.659 \\
(1.288)\end{array}$ & $\begin{array}{r}2.568^{* * *} \\
(3.156)\end{array}$ \\
\hline Independent VC & & & $\begin{array}{r}-0.177 \\
(-0.902)\end{array}$ & \\
\hline VC Size & & & $\begin{array}{r}0.387^{* * *} \\
(4.141)\end{array}$ & \\
\hline VC Age & & & $\begin{array}{r}-0.113 \\
(-0.731)\end{array}$ & \\
\hline VC US Experience & & & $\begin{array}{r}0.316 \\
(1.075)\end{array}$ & \\
\hline Investor Country Fixed Effects & Yes & Yes & Yes & Yes \\
\hline Company Country Fixed Effects & Yes & Yes & Yes & Yes \\
\hline Observations & 1,056 & 1,056 & 1,054 & 621 \\
\hline Pseudo $R^{2}$ & 0.119 & 0.221 & 0.236 & 0.185 \\
\hline
\end{tabular}


Panel B: EXIT

\begin{tabular}{|c|c|c|c|c|}
\hline & $\begin{array}{c}\text { (i) } \\
\text { EXIT } \\
\text { Logit } \\
\end{array}$ & $\begin{array}{c}\text { (ii) } \\
\text { EXIT } \\
\text { Logit }\end{array}$ & $\begin{array}{c}\text { (iii) } \\
\text { EXIT } \\
\text { Logit }\end{array}$ & $\begin{array}{c}\text { (iv) } \\
\text { EXIT } \\
\text { Cond. Logit }\end{array}$ \\
\hline Trust & $\begin{array}{l}-4.426^{*} \\
(-1.805)\end{array}$ & $\begin{array}{r}-3.632 \\
(-1.432)\end{array}$ & $\begin{array}{r}-4.116 \\
(-1.602)\end{array}$ & $\begin{array}{r}-2.489 \\
(-0.781)\end{array}$ \\
\hline Information & $\begin{array}{r}2.196 \\
(1.297)\end{array}$ & $\begin{array}{r}1.913 \\
(1.076)\end{array}$ & $\begin{array}{r}1.548 \\
(0.894)\end{array}$ & $\begin{array}{r}1.339 \\
(0.512)\end{array}$ \\
\hline GDP Difference & $\begin{array}{r}-1.549 \\
(-0.613)\end{array}$ & $\begin{array}{r}-1.552 \\
(-0.595)\end{array}$ & $\begin{array}{r}-2.211 \\
(-0.826)\end{array}$ & $\begin{array}{r}-0.289 \\
(-0.080)\end{array}$ \\
\hline Language Overlap & $\begin{array}{r}-0.700 \\
(-0.909)\end{array}$ & $\begin{array}{r}-0.546 \\
(-0.714)\end{array}$ & $\begin{array}{r}-1.206 \\
(-1.624)\end{array}$ & $\begin{array}{r}-0.813 \\
(-0.891)\end{array}$ \\
\hline Legal Difference & $\begin{array}{r}0.690 \\
(1.434)\end{array}$ & $\begin{array}{r}0.715 \\
(1.498)\end{array}$ & $\begin{array}{c}1.099 * * \\
(2.306)\end{array}$ & $\begin{array}{r}0.611 \\
(0.981)\end{array}$ \\
\hline Distance & & $\begin{array}{r}0.028 \\
(0.769)\end{array}$ & $\begin{array}{r}0.031 \\
(0.824)\end{array}$ & $\begin{array}{r}0.036 \\
(1.024)\end{array}$ \\
\hline Foreign Deal & $\begin{array}{l}-2.102^{*} \\
(-1.960)\end{array}$ & $\begin{array}{r}-1.808 \\
(-1.582)\end{array}$ & $\begin{array}{r}-3.035^{* * *} \\
(-2.734)\end{array}$ & $\begin{array}{r}-2.059 \\
(-1.396)\end{array}$ \\
\hline Common Border & $\begin{array}{r}0.666 \\
(1.599)\end{array}$ & $\begin{array}{r}0.592 \\
(1.441)\end{array}$ & $\begin{array}{r}0.642 \\
(1.494)\end{array}$ & $\begin{array}{c}0.695^{*} \\
(1.867)\end{array}$ \\
\hline Early Stage & & $\begin{array}{r}-0.419^{* * *} \\
(-2.722)\end{array}$ & $\begin{array}{r}-0.426^{* * *} \\
(-2.742)\end{array}$ & $\begin{array}{r}-0.315^{* *} \\
(-2.163)\end{array}$ \\
\hline Industry Fit & & $\begin{array}{r}0.362 \\
(0.574)\end{array}$ & $\begin{array}{r}-0.101 \\
(-0.232)\end{array}$ & $\begin{array}{r}0.654 \\
(1.205)\end{array}$ \\
\hline Stage Fit & & $\begin{array}{r}-0.305 \\
(-1.135)\end{array}$ & $\begin{array}{r}0.038 \\
(0.199)\end{array}$ & $\begin{array}{r}0.209 \\
(0.561)\end{array}$ \\
\hline Independent VC & & & $\begin{array}{r}0.068 \\
(0.578)\end{array}$ & \\
\hline VC Size & & & $\begin{array}{r}0.357^{* * *} \\
(5.815)\end{array}$ & \\
\hline VC Age & & & $\begin{array}{l}-0.148^{*} \\
(-1.735)\end{array}$ & \\
\hline VC US Experience & & & $\begin{array}{r}0.595^{* * *} \\
(3.200)\end{array}$ & \\
\hline Investor Country Fixed Effects & Yes & Yes & Yes & Yes \\
\hline Company Country Fixed Effects & Yes & Yes & Yes & Yes \\
\hline Observations & 1,131 & 1,131 & 1,125 & 1,037 \\
\hline Pseudo $R^{2}$ & 0.063 & 0.100 & 0.124 & 0.052 \\
\hline
\end{tabular}


Panel C: FAILURE

\begin{tabular}{|c|c|c|c|c|}
\hline & $\begin{array}{c}\text { (i) } \\
\text { FAILURE } \\
\text { Logit }\end{array}$ & $\begin{array}{c}\text { (ii) } \\
\text { FAILURE } \\
\text { Logit }\end{array}$ & $\begin{array}{c}\text { (iii) } \\
\text { FAILURE } \\
\text { Logit }\end{array}$ & $\begin{array}{c}\text { (iv) } \\
\text { FAILURE } \\
\text { Cond. Logit }\end{array}$ \\
\hline Trust & $\begin{array}{r}7.081^{* * *} \\
(3.048)\end{array}$ & $\begin{array}{r}5.700^{* *} \\
(2.170)\end{array}$ & $\begin{array}{r}5.980^{* *} \\
(2.023)\end{array}$ & $\begin{array}{r}5.977 \\
(1.606)\end{array}$ \\
\hline Information & $\begin{array}{r}-5.075 * * * \\
(-3.615)\end{array}$ & $\begin{array}{r}-4.508^{* * * *} \\
(-3.181)\end{array}$ & $\begin{array}{r}-4.204^{* * *} \\
(-2.796)\end{array}$ & $\begin{array}{r}-5.264^{* *} \\
(-2.094)\end{array}$ \\
\hline GDP Difference & $\begin{array}{r}3.556 \\
(1.171)\end{array}$ & $\begin{array}{r}3.391 \\
(1.102)\end{array}$ & $\begin{array}{r}4.293 \\
(1.340)\end{array}$ & $\begin{array}{r}2.575 \\
(0.704)\end{array}$ \\
\hline Language Overlap & $\begin{array}{r}-0.016 \\
(-0.021)\end{array}$ & $\begin{array}{r}-0.062 \\
(-0.078)\end{array}$ & $\begin{array}{r}0.638 \\
(0.817)\end{array}$ & $\begin{array}{r}0.272 \\
(0.320)\end{array}$ \\
\hline Legal Difference & $\begin{array}{r}-0.814 \\
(-1.575)\end{array}$ & $\begin{array}{r}-0.849 \\
(-1.575)\end{array}$ & $\begin{array}{r}-1.301^{* *} \\
(-2.354)\end{array}$ & $\begin{array}{r}-1.121^{* *} \\
(-2.049)\end{array}$ \\
\hline Distance & & $\begin{array}{r}-0.044 \\
(-1.071)\end{array}$ & $\begin{array}{r}-0.047 \\
(-1.085)\end{array}$ & $\begin{array}{r}-0.057 \\
(-1.541)\end{array}$ \\
\hline Foreign Deal & $\begin{array}{c}2.332^{* *} \\
(2.180)\end{array}$ & $\begin{array}{l}2.080^{*} \\
(1.753)\end{array}$ & $\begin{array}{r}3.371^{* * *} \\
(2.685)\end{array}$ & $\begin{array}{r}3.133^{* *} \\
(2.205)\end{array}$ \\
\hline Common Border & $\begin{array}{r}-0.391 \\
(-1.006)\end{array}$ & $\begin{array}{r}-0.329 \\
(-0.854)\end{array}$ & $\begin{array}{r}-0.320 \\
(-0.793)\end{array}$ & $\begin{array}{r}-0.492 \\
(-1.019)\end{array}$ \\
\hline Early Stage & & $\begin{array}{r}0.502^{* * *} \\
(2.838)\end{array}$ & $\begin{array}{r}0.526^{* * *} \\
(2.979)\end{array}$ & $\begin{array}{r}0.447^{* *} * \\
(2.560)\end{array}$ \\
\hline Industry Fit & & $\begin{array}{r}-0.319 \\
(-0.498)\end{array}$ & $\begin{array}{r}0.243 \\
(0.602)\end{array}$ & $\begin{array}{r}-0.445 \\
(-1.059)\end{array}$ \\
\hline Stage Fit & & $\begin{array}{r}-0.001 \\
(-0.005)\end{array}$ & $\begin{array}{r}-0.303 \\
(-1.502)\end{array}$ & $\begin{array}{r}-0.573 \\
(-1.384)\end{array}$ \\
\hline Independent VC & & & $\begin{array}{r}-0.341^{* *} \\
(-2.462)\end{array}$ & \\
\hline VC Size & & & $\begin{array}{r}-0.394^{* * *} \\
(-8.112)\end{array}$ & \\
\hline VC Age & & & $\begin{array}{r}0.172^{* *} \\
(2.100)\end{array}$ & \\
\hline VC US Experience & & & $\begin{array}{r}-0.673^{* * *} \\
(-3.397)\end{array}$ & \\
\hline Investor Country Fixed Effects & Yes & Yes & Yes & Yes \\
\hline Company Country Fixed Effects & Yes & Yes & Yes & Yes \\
\hline Observations & 1,131 & 1,131 & 1,125 & 1,045 \\
\hline Pseudo $R^{2}$ & 0.085 & 0.115 & 0.146 & 0.051 \\
\hline
\end{tabular}




\section{Table 4 \\ Selection}

This table reports results on how selection may affect investment performance. Variables are defined in Table 1. Panel A reports pairwise correlations between two trust measures and the predicted probabilities of IPO, EXIT, and FAILURE based on information observable at the time of the deal- $\operatorname{Pr}($ IPO), $\operatorname{Pr}(\mathrm{EXIT})$, and Pr(FAILURE), respectively. Under the each correlation coefficient we report the corresponding significance level. Panel B reports results of a Heckman selection model. The dependent variables are IPO, EXIT, and FAILURE. The outcome equation is a logit regression with the same specification as in column (iii) of Table 5; the excluded variable is EXPORTS. Investor controls are measures of investors' size and age, and a set of dummies for each investor's country, type (independent vs. captive), and US experience. Company controls are a set of dummies for each company's country, industry and stage, and for the year the deal was completed. The Heckman model is discussed in Section 4.2. For each independent variable, we report the estimated coefficient and the z-score (in parenthesis) computed using (Huber-White) heteroskedasticity-robust standard errors, clustered by country-dyad. Values significant at the $1 \%, 5 \%$ and $10 \%$ level are identified by $* * *, * *, *$.

Panel A: Selection on observables: Pairwise correlations

\begin{tabular}{lrrr}
\hline \hline & (i) & (ii) & \multicolumn{1}{c}{ (iii) } \\
& $\operatorname{Pr}(\mathrm{IPO})$ & $\operatorname{Pr}(\mathrm{EXIT})$ & $\operatorname{Pr}(\mathrm{FAILURE})$ \\
\hline \multirow{2}{*}{ Trust } & $-0.236^{* * *}$ & $-0.270^{* * *}$ & $0.355^{* * *}$ \\
& $(-0.000)$ & $(-0.000)$ & $(0.000)$ \\
& & & \\
Trust-residual & $-0.223^{* * *}$ & $-0.425^{* * *}$ & $0.520^{* * *}$ \\
& $(-0.000)$ & $(-0.000)$ & $(-0.000)$ \\
& & & \\
\hline Observations & 1,108 & 1,131 & 1,131 \\
\hline \hline
\end{tabular}


Panel B: Selection on unobservables: Heckman model

\begin{tabular}{|c|c|c|c|}
\hline & $\begin{array}{c}\text { i) } \\
\text { IPO } \\
\text { Heckman }\end{array}$ & $\begin{array}{c}\text { (ii) } \\
\text { EXIT } \\
\text { Heckman }\end{array}$ & $\begin{array}{c}\text { (iii) } \\
\text { FAILURE } \\
\text { Heckman }\end{array}$ \\
\hline Trust & $\begin{array}{c}-0.973^{* *} \\
(-2.511)\end{array}$ & $\begin{array}{r}-0.998 \\
(-1.481)\end{array}$ & $\begin{array}{c}1.301^{*} \\
(1.920)\end{array}$ \\
\hline Information & $\begin{array}{r}-0.345 \\
(-1.548)\end{array}$ & $\begin{array}{r}0.139 \\
(0.358)\end{array}$ & $\begin{array}{r}-0.606 \\
(-1.555)\end{array}$ \\
\hline GDP Difference & $\begin{array}{r}-0.591 \\
(-1.285)\end{array}$ & $\begin{array}{r}-0.328 \\
(-0.410)\end{array}$ & $\begin{array}{r}0.688 \\
(0.855)\end{array}$ \\
\hline Language Overlap & $\begin{array}{r}-0.120 \\
(-0.944)\end{array}$ & $\begin{array}{r}-0.262 \\
(-1.181)\end{array}$ & $\begin{array}{r}0.176 \\
(0.791)\end{array}$ \\
\hline Legal Difference & $\begin{array}{r}0.066 \\
(0.862)\end{array}$ & $\begin{array}{r}0.211 \\
(1.581)\end{array}$ & $\begin{array}{l}-0.256^{*} \\
(-1.901)\end{array}$ \\
\hline Distance & $\begin{array}{r}-0.002 \\
(-0.438)\end{array}$ & $\begin{array}{r}0.011 \\
(1.547)\end{array}$ & $\begin{array}{l}-0.014^{*} \\
(-1.930)\end{array}$ \\
\hline Foreign Deal & $\begin{array}{r}-0.226 \\
(-1.243)\end{array}$ & $\begin{array}{l}-0.555^{*} \\
(-1.761)\end{array}$ & $\begin{array}{r}0.648^{* *} \\
(2.041)\end{array}$ \\
\hline Common Border & $\begin{array}{r}0.081 \\
(1.336)\end{array}$ & $\begin{array}{r}0.154 \\
(1.468)\end{array}$ & $\begin{array}{r}-0.084 \\
(-0.795)\end{array}$ \\
\hline Early Stage & $\begin{array}{r}-0.071^{* * *} \\
(-3.930)\end{array}$ & $\begin{array}{r}-0.067^{* *} \\
(-2.146)\end{array}$ & $\begin{array}{r}0.093^{* * *} \\
(2.946)\end{array}$ \\
\hline Industry Fit & $\begin{array}{l}-0.100^{*} \\
(-1.758)\end{array}$ & $\begin{array}{r}-0.132 \\
(-1.345)\end{array}$ & $\begin{array}{r}0.147 \\
(1.490)\end{array}$ \\
\hline Stage Fit & $\begin{array}{r}-0.026 \\
(-0.627)\end{array}$ & $\begin{array}{r}-0.041 \\
(-0.579)\end{array}$ & $\begin{array}{r}-0.026 \\
(-0.370)\end{array}$ \\
\hline Independent VC & $\begin{array}{r}-0.003 \\
(-0.136)\end{array}$ & $\begin{array}{r}0.027 \\
(0.745)\end{array}$ & $\begin{array}{r}-0.082^{* *} \\
(-2.230)\end{array}$ \\
\hline VC Size & $\begin{array}{c}0.017^{*} \\
(1.886)\end{array}$ & $\begin{array}{r}0.068^{* * *} \\
(4.340)\end{array}$ & $\begin{array}{r}-0.080^{* * *} \\
(-5.096)\end{array}$ \\
\hline VC Age & $\begin{array}{r}-0.012 \\
(-1.028)\end{array}$ & $\begin{array}{c}-0.037^{*} \\
(-1.816)\end{array}$ & $\begin{array}{r}0.043^{* *} \\
(2.101)\end{array}$ \\
\hline VC US Experience & $\begin{array}{r}0.024 \\
(1.020)\end{array}$ & $\begin{array}{r}0.126^{* * *} \\
(3.064)\end{array}$ & $\begin{array}{r}-0.145^{* * *} \\
(-3.499)\end{array}$ \\
\hline & \multicolumn{3}{|c|}{ SELECTION EQUATION } \\
\hline Trust & $\begin{array}{r}1.856^{* * *} \\
(3.615)\end{array}$ & $\begin{array}{r}1.856^{* * *} \\
(3.615)\end{array}$ & $\begin{array}{r}1.856^{* * *} \\
(3.615)\end{array}$ \\
\hline Exports & $\begin{array}{r}5.410^{* * *} \\
(6.824)\end{array}$ & $\begin{array}{r}5.410^{* * *} \\
(6.824)\end{array}$ & $\begin{array}{r}5.410^{* * *} \\
(6.824)\end{array}$ \\
\hline Mill's $\lambda$ & $\begin{array}{c}-0.067^{* *} \\
(-2.548)\end{array}$ & $\begin{array}{l}-0.077^{*} \\
(-1.678)\end{array}$ & $\begin{array}{r}0.061 \\
(1.342)\end{array}$ \\
\hline Investor Controls & Yes & Yes & Yes \\
\hline Company Controls & Yes & Yes & Yes \\
\hline Observations & 101,614 & 101,614 & 101,614 \\
\hline Realized deals & 1,129 & 1,129 & 1,129 \\
\hline Wald $\chi^{2}(59)$ & 211.59 & 205.74 & 259.39 \\
\hline
\end{tabular}


Table 5

\section{Deal Structure: Early Stage}

This table reports results of regressions for the realized deals sample. Variables are defined in Table 1. The dependent variables are EARLY STAGE and STAGE. Columns (i) and (ii) report results of logit regressions, with EARLY STAGE as dependent variable. Ccolumns (iii) and (iv) report results of ordered logit regresssions, with STAGE as dependent variable. These models are discussed in Section 5.1. For each independent variable, we report the estimated coefficient and the z-score (in parenthesis) computed using (Huber-White) heteroskedasticity-robust standard errors, clustered by country-dyad. Values significant at the 1\%, 5\% and $10 \%$ level are identified by $* * *, * *, *$.

\begin{tabular}{|c|c|c|c|c|}
\hline & $\begin{array}{c}\text { EARLY STAGE } \\
\text { Logit }\end{array}$ & $\begin{array}{c}\text { (ii) } \\
\text { EARLY STAGE } \\
\text { Logit }\end{array}$ & $\begin{array}{c}\text { (iii) } \\
\text { STAGE } \\
\text { Ord. Logit }\end{array}$ & $\begin{array}{c}\text { (iv) } \\
\text { STAGE } \\
\text { Ord. Logit }\end{array}$ \\
\hline Trust & $\begin{array}{r}4.700 \\
(1.587)\end{array}$ & $\begin{array}{c}5.637^{*} \\
(1.784)\end{array}$ & $\begin{array}{r}-5.828^{* *} \\
(-2.229)\end{array}$ & $\begin{array}{c}-5.691^{*} \\
(-1.858)\end{array}$ \\
\hline Information & $\begin{array}{r}-2.936 \\
(-1.616)\end{array}$ & $\begin{array}{r}-2.700 \\
(-1.194)\end{array}$ & $\begin{array}{r}0.138 \\
(0.119)\end{array}$ & $\begin{array}{r}-0.797 \\
(-0.573)\end{array}$ \\
\hline GDP Difference & $\begin{array}{r}-0.637 \\
(-0.150)\end{array}$ & $\begin{array}{r}0.439 \\
(0.085)\end{array}$ & $\begin{array}{r}1.488 \\
(0.608)\end{array}$ & $\begin{array}{r}0.995 \\
(0.362)\end{array}$ \\
\hline Language Overlap & $\begin{array}{r}-0.828 \\
(-0.972)\end{array}$ & $\begin{array}{r}-0.185 \\
(-0.247)\end{array}$ & $\begin{array}{r}0.232 \\
(0.357)\end{array}$ & $\begin{array}{r}-0.287 \\
(-0.464)\end{array}$ \\
\hline Legal Difference & $\begin{array}{r}0.823 \\
(1.020)\end{array}$ & $\begin{array}{r}0.582 \\
(0.669)\end{array}$ & $\begin{array}{r}-0.564 \\
(-1.102)\end{array}$ & $\begin{array}{r}-0.238 \\
(-0.437)\end{array}$ \\
\hline Distance & & $\begin{array}{r}-0.096^{* *} \\
(-2.420)\end{array}$ & & $\begin{array}{r}0.088^{* * *} \\
(2.913)\end{array}$ \\
\hline Foreign Deal & $\begin{array}{r}0.483 \\
(0.361)\end{array}$ & $\begin{array}{r}1.920 \\
(1.401)\end{array}$ & $\begin{array}{r}-1.302 \\
(-1.144)\end{array}$ & $\begin{array}{l}-2.313^{*} \\
(-1.798)\end{array}$ \\
\hline Common Border & $\begin{array}{r}-0.150 \\
(-0.267)\end{array}$ & $\begin{array}{r}-0.173 \\
(-0.302)\end{array}$ & $\begin{array}{r}0.344 \\
(0.850)\end{array}$ & $\begin{array}{r}0.314 \\
(0.713)\end{array}$ \\
\hline Industry Fit & & $\begin{array}{r}0.067 \\
(0.243)\end{array}$ & & $\begin{array}{c}0.394^{*} \\
(1.708)\end{array}$ \\
\hline Stage Fit & & $\begin{array}{r}1.875^{* *} \\
(2.065)\end{array}$ & & $\begin{array}{r}-1.708^{* * *} \\
(-2.686)\end{array}$ \\
\hline Independent VC & & $\begin{array}{r}-0.132 \\
(-0.582)\end{array}$ & & $\begin{array}{r}-0.051 \\
(-0.135)\end{array}$ \\
\hline VC Size & & $\begin{array}{r}-0.325^{* * *} \\
(-3.538)\end{array}$ & & $\begin{array}{r}0.374^{* * *} \\
(5.103)\end{array}$ \\
\hline VC Age & & $\begin{array}{r}-0.043 \\
(-0.296)\end{array}$ & & $\begin{array}{r}0.068 \\
(0.529)\end{array}$ \\
\hline VC US Experience & & $\begin{array}{r}0.186 \\
(0.555)\end{array}$ & & $\begin{array}{r}-0.256 \\
(-0.800)\end{array}$ \\
\hline Investor Country Fixed Effects & Yes & Yes & Yes & Yes \\
\hline Company Country Fixed Effects & Yes & Yes & Yes & Yes \\
\hline Observations & 1,228 & 1,222 & 1,222 & 1,216 \\
\hline Pseudo $R^{2}$ & 0.096 & 0.178 & 0.053 & 0.119 \\
\hline
\end{tabular}




\section{Table 6}

\section{Deal Structure: Syndication}

This table reports results of logit regressions for the realized deals sample. Variables are defined in Table 1. The dependent variable is SYNDICATION. These models are discussed in Section 5.2. For each independent variable, we report the estimated coefficient and the z-score (in parenthesis) computed using (Huber-White) heteroskedasticity-robust standard errors, clustered by country-dyad. Values significant at the 1\%, $5 \%$ and $10 \%$ level are identified by $* * *, * *, *$.

\begin{tabular}{|c|c|c|}
\hline & $\begin{array}{c}\text { (i) } \\
\text { SYNDICATION } \\
\text { Logit }\end{array}$ & $\begin{array}{c}\text { (ii) } \\
\text { SYNDICATION } \\
\text { Logit }\end{array}$ \\
\hline Trust & $\begin{array}{r}-9.800^{* *} \\
(-2.437)\end{array}$ & $\begin{array}{r}-9.279^{* *} \\
(-2.255)\end{array}$ \\
\hline Information & $\begin{array}{r}2.444 \\
(1.068)\end{array}$ & $\begin{array}{r}2.136 \\
(0.952)\end{array}$ \\
\hline GDP Difference & $\begin{array}{r}-12.286^{* * *} \\
(-2.820)\end{array}$ & $\begin{array}{r}-12.867^{* * *} \\
(-3.109)\end{array}$ \\
\hline Language Overlap & $\begin{array}{r}-2.921^{* * *} \\
(-2.598)\end{array}$ & $\begin{array}{r}-3.125^{* * *} \\
(-2.775)\end{array}$ \\
\hline Legal Difference & $\begin{array}{r}1.746^{* * *} \\
(2.832)\end{array}$ & $\begin{array}{r}2.125^{* * *} \\
(3.069)\end{array}$ \\
\hline Distance & $\begin{array}{r}-0.017 \\
(-0.564)\end{array}$ & $\begin{array}{r}-0.032 \\
(-1.209)\end{array}$ \\
\hline Foreign Deal & $\begin{array}{r}-4.798^{* * *} \\
(-3.044)\end{array}$ & $\begin{array}{r}-5.150^{* * *} \\
(-2.845)\end{array}$ \\
\hline Common Border & $\begin{array}{r}-0.012 \\
(-0.021)\end{array}$ & $\begin{array}{r}0.012 \\
(0.020)\end{array}$ \\
\hline Early Stage & & $\begin{array}{r}0.362^{*} \\
(1.664)\end{array}$ \\
\hline Industry Fit & & $\begin{array}{r}0.451 \\
(0.703)\end{array}$ \\
\hline Stage Fit & & $\begin{array}{r}0.025 \\
(0.046)\end{array}$ \\
\hline Independent VC & & $\begin{array}{r}-0.274 \\
(-0.521)\end{array}$ \\
\hline VC Size & & $\begin{array}{r}0.213 \\
(1.391)\end{array}$ \\
\hline VC Age & & $\begin{array}{r}-0.043 \\
(-0.105)\end{array}$ \\
\hline VC US Experience & & $\begin{array}{r}0.437 \\
(1.277)\end{array}$ \\
\hline $\begin{array}{l}\text { Investor Country Fixed Effects } \\
\text { Company Country Fixed Effects }\end{array}$ & $\begin{array}{l}\text { Yes } \\
\text { Yes }\end{array}$ & $\begin{array}{l}\text { Yes } \\
\text { Yes }\end{array}$ \\
\hline $\begin{array}{l}\text { Observations } \\
\text { Pseudo } R^{2}\end{array}$ & $\begin{array}{l}1,094 \\
0.070\end{array}$ & $\begin{array}{l}1,092 \\
0.120\end{array}$ \\
\hline
\end{tabular}




\section{Table 7}

\section{Deal Structure: Contingent Contracts}

This table reports results of regressions for the realized deals sample. Variables are defined in Table 1. The dependent variables are an index summary of use of contingent contracts and individual dummies for each contractual clause. Column (i) reports results of a poisson regression. Columns (ii) to (v) report results of logit regressions. These models are discussed in Section 5.3. For each independent variable, we report the estimated coefficient and the z-score (in parenthesis) computed using (Huber-White) heteroskedasticity-robust standard errors, clustered by country-dyad. Values significant at the $1 \%, 5 \%$ and $10 \%$ level are identified by $* * *, * *, *$.

\begin{tabular}{|c|c|c|c|c|c|}
\hline & $\begin{array}{c}\text { (i) } \\
\text { CC-INDEX } \\
\text { Poisson } \\
\end{array}$ & $\begin{array}{c}\text { (ii) } \\
\text { CC-Board } \\
\text { Logit } \\
\end{array}$ & $\begin{array}{c}\text { (iii) } \\
\text { CC-Voting } \\
\text { Logit } \\
\end{array}$ & $\begin{array}{c}\text { (iv) } \\
\text { CC-Liquidation } \\
\text { Logit } \\
\end{array}$ & $\begin{array}{c}(\mathrm{v}) \\
\text { CC-Termination } \\
\text { Logit } \\
\end{array}$ \\
\hline Trust & $\begin{array}{r}3.580^{* *} \\
(2.550)\end{array}$ & $\begin{array}{l}11.086 \\
(1.538)\end{array}$ & $\begin{array}{r}22.209^{* * *} \\
(4.754)\end{array}$ & $\begin{array}{c}10.322 \\
(1.642)\end{array}$ & $\begin{array}{r}13.653^{*} \\
(1.867)\end{array}$ \\
\hline Information & $\begin{array}{r}1.142 \\
(1.543)\end{array}$ & $\begin{array}{r}-1.271 \\
(-0.282)\end{array}$ & $\begin{array}{r}1.222 \\
(0.531)\end{array}$ & $\begin{array}{r}6.349^{* * *} \\
(2.884)\end{array}$ & $\begin{array}{r}7.933^{* * *} * \\
(4.585)\end{array}$ \\
\hline GDP Difference & $\begin{array}{r}0.046 \\
(0.031)\end{array}$ & $\begin{array}{l}-11.092 \\
(-1.532)\end{array}$ & $\begin{array}{r}9.913 \\
(1.100)\end{array}$ & $\begin{array}{r}-3.673 \\
(-0.584)\end{array}$ & $\begin{array}{l}8.391^{*} \\
(1.756)\end{array}$ \\
\hline Language Overlap & $\begin{array}{r}-0.123 \\
(-0.280)\end{array}$ & $\begin{array}{r}-4.633^{* * *} \\
(-3.313)\end{array}$ & $\begin{array}{c}2.529^{*} \\
(1.728)\end{array}$ & $\begin{array}{r}1.863 \\
(1.267)\end{array}$ & $\begin{array}{r}0.877 \\
(0.546)\end{array}$ \\
\hline Legal Difference & $\begin{array}{r}-0.010 \\
(-0.031)\end{array}$ & $\begin{array}{l}1.837^{*} \\
(1.774)\end{array}$ & $\begin{array}{r}-1.427 \\
(-1.387)\end{array}$ & $\begin{array}{r}-1.413 \\
(-1.318)\end{array}$ & $\begin{array}{r}-0.306 \\
(-0.212)\end{array}$ \\
\hline Distance & $\begin{array}{r}-0.009 \\
(-0.729)\end{array}$ & $\begin{array}{r}0.039 \\
(1.292)\end{array}$ & $\begin{array}{r}-0.137^{* * *} \\
(-4.214)\end{array}$ & $\begin{array}{r}0.034 \\
(1.574)\end{array}$ & $\begin{array}{r}-0.026 \\
(-0.874)\end{array}$ \\
\hline Foreign Deal & $\begin{array}{r}0.717 \\
(1.025)\end{array}$ & $\begin{array}{r}-1.885 \\
(-0.760)\end{array}$ & $\begin{array}{r}8.760^{* * *} \\
(3.725)\end{array}$ & $\begin{array}{l}4.938^{*} \\
(1.757)\end{array}$ & $\begin{array}{r}3.915 \\
(1.008)\end{array}$ \\
\hline Common Border & $\begin{array}{r}-0.653^{* *} \\
(-2.437)\end{array}$ & $\begin{array}{r}-1.417 \\
(-1.606)\end{array}$ & $\begin{array}{r}-0.627 \\
(-0.894)\end{array}$ & $\begin{array}{r}-1.846^{* *} \\
(-2.480)\end{array}$ & $\begin{array}{r}-2.742^{* * *} \\
(-3.546)\end{array}$ \\
\hline Early Stage & $\begin{array}{r}0.019 \\
(0.239)\end{array}$ & $\begin{array}{r}-0.228 \\
(-0.976)\end{array}$ & $\begin{array}{r}0.059 \\
(0.231)\end{array}$ & $\begin{array}{r}0.119 \\
(0.550)\end{array}$ & $\begin{array}{r}-0.006 \\
(-0.021)\end{array}$ \\
\hline Industry Fit & $\begin{array}{r}-0.246 \\
(-0.727)\end{array}$ & $\begin{array}{r}0.728 \\
(0.744)\end{array}$ & $\begin{array}{l}-1.049^{*} \\
(-1.684)\end{array}$ & $\begin{array}{r}-1.359 \\
(-1.525)\end{array}$ & $\begin{array}{r}-0.252 \\
(-0.312)\end{array}$ \\
\hline Stage Fit & $\begin{array}{r}0.022 \\
(0.098)\end{array}$ & $\begin{array}{r}0.730 \\
(1.137)\end{array}$ & $\begin{array}{r}0.083 \\
(0.177)\end{array}$ & $\begin{array}{r}-0.490 \\
(-1.255)\end{array}$ & $\begin{array}{r}0.585 \\
(0.663)\end{array}$ \\
\hline Independent VC & $\begin{array}{r}-0.402^{* *} \\
(-2.007)\end{array}$ & $\begin{array}{r}-0.513 \\
(-0.826)\end{array}$ & $\begin{array}{r}-0.842 \\
(-1.304)\end{array}$ & $\begin{array}{r}-0.940 \\
(-1.174)\end{array}$ & $\begin{array}{r}-1.622^{* * *} \\
(-2.923)\end{array}$ \\
\hline VC Size & $\begin{array}{r}0.017 \\
(0.236)\end{array}$ & $\begin{array}{r}-0.196 \\
(-0.514)\end{array}$ & $\begin{array}{r}-0.173 \\
(-0.698)\end{array}$ & $\begin{array}{r}0.227 \\
(0.742)\end{array}$ & $\begin{array}{r}0.105 \\
(0.795)\end{array}$ \\
\hline VC Age & $\begin{array}{r}-0.436^{* * *} \\
(-2.888)\end{array}$ & $\begin{array}{r}-0.990 * * * \\
(-2.892)\end{array}$ & $\begin{array}{r}-0.841 * * * \\
(-2.646)\end{array}$ & $\begin{array}{r}-1.094^{* * *} \\
(-2.902)\end{array}$ & $\begin{array}{r}-0.737^{* *} \\
(-2.231)\end{array}$ \\
\hline VC US Experience & $\begin{array}{r}0.122 \\
(0.613)\end{array}$ & $\begin{array}{r}-0.819^{* *} \\
(-2.453)\end{array}$ & $\begin{array}{r}0.769 \\
(1.266)\end{array}$ & $\begin{array}{r}1.219 \\
(1.546)\end{array}$ & $\begin{array}{r}0.845 \\
(1.281)\end{array}$ \\
\hline Investor Country Fixed Effects & Yes & Yes & Yes & Yes & Yes \\
\hline Company Country Fixed Effects & Yes & Yes & Yes & Yes & Yes \\
\hline Observations & 1,087 & 1,076 & 1,003 & 1,005 & 1,005 \\
\hline Pseudo $R^{2}$ & - & 0.314 & 0.333 & 0.269 & 0.275 \\
\hline
\end{tabular}


Figure 1: Trust and VC market size

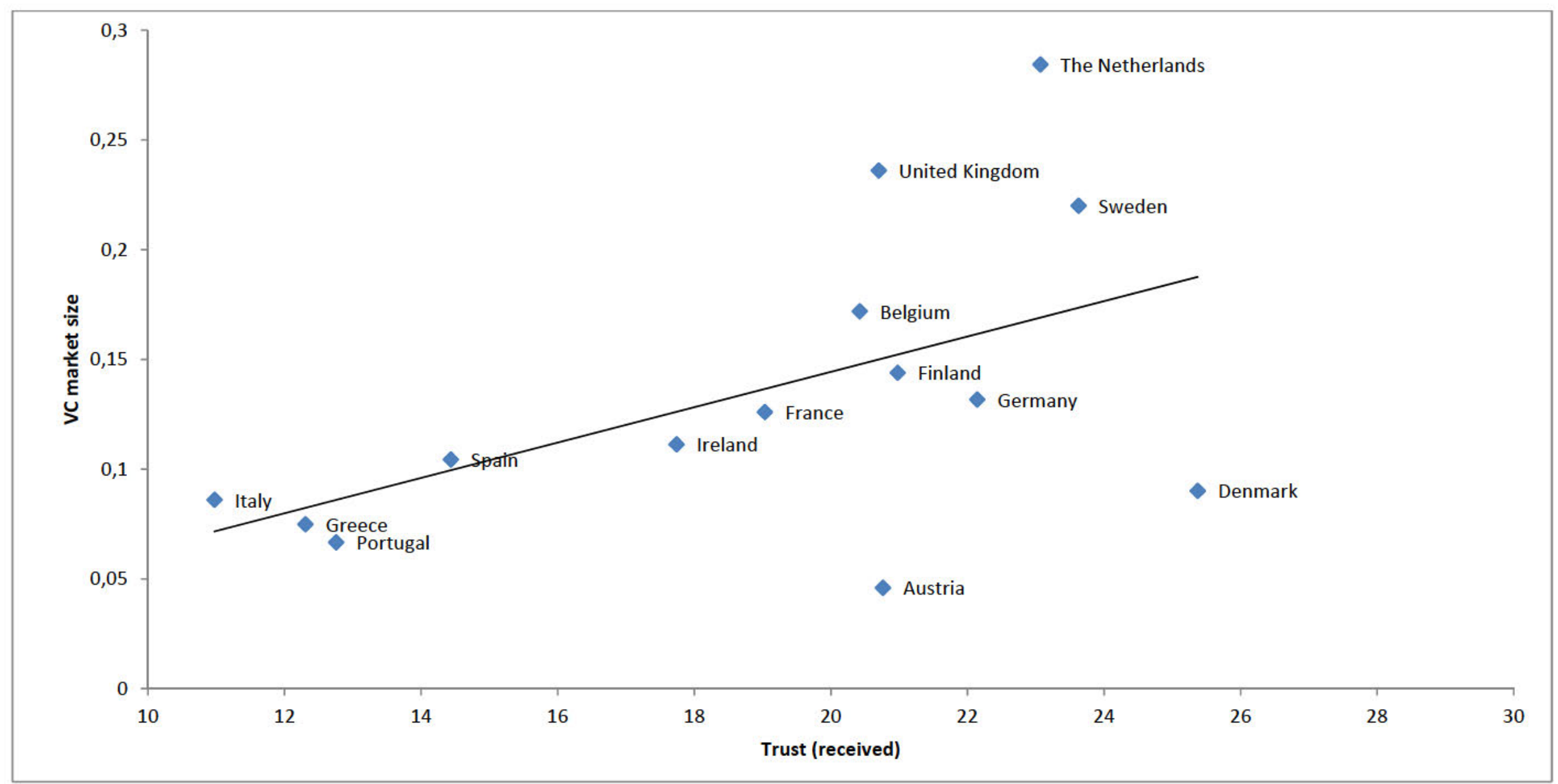

This figure shows the relationship between countries' trust and the size of their venture capital market. Each observation represents a country in our dataset. Trust (received) is the average percentage of people who expressed high trust in the Eurobarometer data over the 1990-1996 period. A value of 20 means that on average $20 \%$ of people expressed high trust. VC market size is measured as the total venture capital investments divided by the country's per-capita GDP, for the period 1998-2001. 